BIS WORKING PAPERS

No. 82 - November 1999

\title{
SACRIFICE RATIOS AND THE CONDUCT OF MONETARY POLICY IN CONDITIONS OF LOW INFLATION
}

by

Palle S Andersen and William L Wascher

BANK FOR INTERNATIONAL SETTLEMENTS

Monetary and Economic Department

Basel, Switzerland 
BIS Working Papers are written by members of the Monetary and Economic Department of the Bank for International Settlements, and from time to time by other economists, and are published by the Bank. The papers are on subjects of topical interest and are technical in character. The views expressed in them are those of their authors and not necessarily the views of the BIS.

Copies of publications are available from:

Bank for International Settlements

Information, Press \& Library Services

$\mathrm{CH}-4002$ Basel, Switzerland

Fax: +41 61 / 2809100 and +4161/2808100

This publication is available on the BIS website (www.bis.org).

(C) Bank for International Settlements 1999.

All rights reserved. Brief excerpts may be reproduced or translated provided the source is stated. 
No. 82 - November 1999

\title{
SACRIFICE RATIOS AND THE CONDUCT OF MONETARY POLICY IN CONDITIONS OF LOW INFLATION
}

by

\author{
Palle S Andersen and William L Wascher*
}

\begin{abstract}
The focus of monetary policy has shifted markedly over the past 15 years away from attempts to fine tune the economy towards the longer-run goal of attaining price stability and creating the necessary conditions for sustainable economic growth. In an attempt to minimise the costs of such a transition, central banks have become more independent and monetary policy more transparent, changes intended to increase the credibility of monetary policy and to reduce short-run sacrifice ratios. However, concerns have been expressed that an environment of price stability and independent central banks may instead lead to higher sacrifice ratios and, perhaps, even higher rates of structural unemployment, because of the increased importance of nominal and real rigidities at low rates of inflation.

The purpose of this paper is to analyse whether there are any grounds for such concerns. We do so by estimating sacrifice ratios for 19 industrialised countries, using three alternative approaches: (1) estimating aggregate supply curves; (2) estimating structural price and wage equations; and (3) comparing actual changes in inflation with changes in standard measures of output and labour market slack. The empirical evidence shows that, as the average rate of inflation for the 19 countries in our sample has fallen from $8 \%$ to $3 \frac{1}{2} \%$, the average sacrifice ratio has increased from around 1.5 to about 2.5. Although sacrifice ratios appear to have risen in virtually all countries, the increases tend to be smallest in those that have adopted measures to deregulate labour and product markets and in countries where the central bank has adopted explicit inflation targets. However, the empirical evidence also reveals that point estimates of the sacrifice ratios for individual countries are quite sensitive to the econometric method adopted. This last result suggests that identification of the sources of higher sacrifice ratios remains elusive and thus that one should be cautious about drawing strong implications for monetary policy from these kinds of estimates.
\end{abstract}

* We gratefully recognise comments on an earlier draft by J D Amato, T Andersen, R Filosa and participants at seminars at the BIS, the Swiss National Bank and the Bank of Greece. 



\section{Contents}

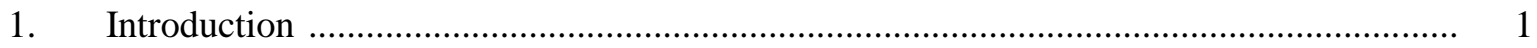

2. Sacrifice ratios estimated from the aggregate supply curve …...................................... 3

3. Sacrifice ratios based on wage and price adjustment equations …...................................... 9

4. Sacrifice ratios during episodes of disinflation ........................................................ 15

5. Inflation, central bank independence and sacrifice ratios f.......................................... 18

6. Comparison of the estimated sacrifice ratios ......................................................... 21

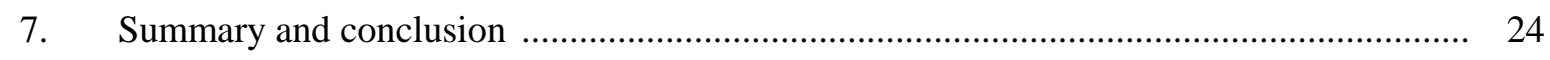

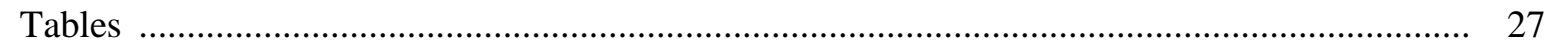

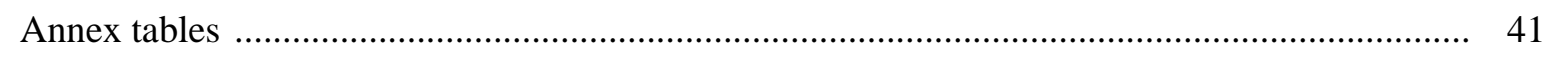

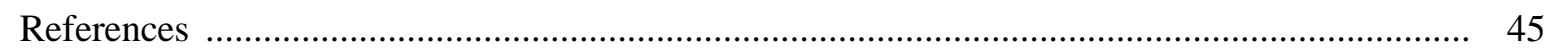





\section{Introduction}

It should by now be clear that one of the primary goals of monetary policy over the past 15 years has been the attainment of price stability. The move towards more independent central banks as well as the adoption of explicit inflation targets by several central banks, clearly stated objectives of "zero inflation" by others and the active interest among central bankers in monetary policy rules illustrate the importance that policymakers have attached to this goal. ${ }^{1}$ And, with rates of inflation falling below 3\% in most industrialised countries and below $1 \%$ in some, central bankers have clearly succeeded in creating one of the necessary conditions for sustainably higher output growth (Table 1).

However, the significant progress that has been made in reducing inflation has also led to new questions about the appropriate conduct of monetary policy in an environment of price stability. One important concern that is frequently expressed is that greater nominal and/or real rigidities may increase sacrifice ratios and perhaps even structural rates of unemployment. ${ }^{2}$ At first glance, a rise in sacrifice ratios might seem surprising. With more independent central banks and firmer commitments to stable prices, one would expect monetary policy to be more credible and sacrifice ratios to fall. However, lack of credibility is not the only factor that, in the past, has prevented an immediate adjustment of inflation expectations to changes in monetary policy. ${ }^{3}$ Potentially more important are various sources of inflation inertia, paradoxically, more credible monetary policies and firmer commitments may have reinforced. Indeed, from a theoretical standpoint, an inverse relationship between nominal rigidities and inflation is implied by some of the new-Keynesian models of wage and price determination in which adjustment costs increase the optimal duration of wage and other contracts and lengthen the time between price adjustments in periods of low inflation. ${ }^{4}$ The backwardlooking component of inflation expectations might increase as well, as agents pay more attention to central bank inflation targets while discounting current price signals and their possible implications for

Fuhrer (1997) argues these tenets of monetary policy may, to some extent, be seen as arising from a literature that explained the high inflation experience of earlier years as a consequence of the time inconsistency problem and the inherent inflation bias of policymakers.

A specific source of concern in this respect has been that nominal wages might be rigid downwards because employees view nominal wage reductions as unfair even though they would readily accept a similar-sized cut in real wages caused by higher prices. If such resistance to nominal wage cuts is prevalent, firms would find it more difficult to adjust real wages downwards at low rates of inflation and thus be forced to make greater use of job cuts in response to weaker demand or adverse productivity shocks. While this does create a risk that structural rates of unemployment are somewhat higher when inflation is low (see, for instance, Akerlof et al. (1996)), lack of convincing empirical evidence on the importance of this particular type of rigidity suggests that such concerns should not be overemphasised. In the following, we therefore focus on other sources of rigidities.

3 See, for instance, Fuhrer (1995).

4 See Gali and Gertler (1998), who find that US firms have lengthened the period between price adjustments from three-four quarters in the 1980s to five-six quarters in the 1990s. Further back, Gordon (1981) found that the degree of nominal inertia increased in the United States during the 1950s as three-year wage contracts became more common. 
future price trends. Real rigidities in labour markets may also change over time, either independently or in conjunction with the decline in inflation. ${ }^{5}$

The standard procedure for analysing the role of rigidities is to calculate sacrifice ratios, which, following Okun (1978, p. 348), can be defined and measured as follows: ${ }^{6}$

"For an extra percentage point of unemployment maintained for a year, the estimated reduction in the ultimate inflation rate at equilibrium unemployment ranges between one-sixth and one-half of 1 percentage point, with an average estimate of 0.3. Or to put it another way, the average estimate of the cost of a 1 point reduction in the basic inflation rate is $10 \%$ of a year's GNP, with a range of 6\% to $18 \% . "$

Okun did not include the details of his calculations, but three features of the measurement are evident: (i) the costs of disinflation refer to a permanent reduction of inflation and not just a temporary one; (ii) the costs are calculated as the cumulative losses during the period of disinflation; and (iii) the losses are usually calculated for a one point reduction in the rate of inflation and can be expressed in terms of either output or unemployment, with the coefficient from the Okune quation (see Okun (1962)) bridging the two.

However, while this general definition is commonly accepted, sacrifice ratios have in practice been estimated using a wide range of different models and methods. ${ }^{7}$ For instance, a number of papers have attempted to estimate sacrifice ratios from the relationship between nominal income changes and real output fluctuations, while others have relied more heavily on structural estimates of price and wage inflation and/or on structural VAR models of various sizes. ${ }^{8}$ A third approach calculates sacrifice ratios from actual developments in output, unemployment and inflation during periods of disinflation.

5 For example, Filardo (1998) estimates a non-linear Phillips curve and finds it to be virtually flat when the output gap is close to zero and the rate of inflation is stable.

Okun used six of the then existing Phillips curve models to derive his estimates. While the models differed widely in structure and size, they all implied that there was no long-run trade-off.

7 Some features, common to most studies, are, however, worth mentioning. Despite progress in computing and modelling techniques, estimates of sacrifice ratios have remained very imprecise. As noted above, Okun (1978) estimated the US sacrifice ratio to be within a range of 6-18\% of GNP using six models. Twenty years later Cecchetti and Rich (1999) find a range of $1.3-9.9 \%$ of GDP, using just three models. Moreover, the definition of sacrifice ratios implicitly assumes that inflation is not a mean-reverting process (i.e. non-stationary either with deterministic breaks in mean or a unit root) while the output and unemployment gaps are stationary. King and Watson (1994) take a slightly different view as they see the existence of an inflation-unemployment (output gap) trade-off at the business cycle horizon as a condition for computing sacrifice ratios. For our country sample, it appears that rates of inflation and output gaps are $\mathrm{I}(1)$ and $\mathrm{I}(0)$, respectively, while, contrary to theory and the implicit assumption, rates of unemployment have generally been non-stationary for the period considered (see Annex Table 1). Finally, another implicit, and mostly untested, assumption concerns the direction of causality and the exogeneity of the variables entering the sacrifice ratio. Most estimates assume that the process of disinflation is initiated by a tightening of monetary policy which then induces a move along the Phillips curve towards higher unemployment and lower inflation. In other words, both unemployment and inflation are endogenous while the policy change is the causal factor.

8 The sacrifice ratios obtained from structural VAR models are highly sensitive to the size of the model (Cecchetti and Rich (1999)) and the identification restrictions imposed (King and Watson (1994)). 
In this paper, we investigate whether the econometric evidence points to a change in the inflation process in the 1990s for a sample of 19 OECD countries, using estimates of the sacrifice ratio derived from several of these alternative approaches. We begin by constructing reduced-form estimates based on methods that use the slope of the short-run aggregate supply curve as a measure of the sacrifice ratio. There are a number of specific techniques that can be included within this grouping, and we discuss the conceptual differences in these procedures as well as differences in the resulting estimates. We then turn to measures that can be derived from structural wage and price equations, with an eye towards identifying whether observed changes in sacrifice ratios originate in product or labour markets. We also compare our econometric estimates with sacrifice ratios calculated from actual developments in output, unemployment and inflation, and examine correlations of our various estimates of the sacrifice ratio with initial rates of inflation and the speed of disinflation. Finally, we attempt to bring together the information from the numerous estimates of the sacrifice ratio that we produce, and to summarise their implications for the conduct of monetary policy.

Taken as a whole, our results indicate that sacrifice ratios have increased as inflation has been reduced and that, for most countries, the sources of the increase can be evenly split between a lower sensitivity of changes in prices and wages to measures of excess supply in product and labour markets and a higher degree of inflation inertia. However, there is also some evidence that in those countries where the process of disinflation has been accompanied by labour and product market reforms, sacrifice ratios based on the unemployment rate have increased less or even declined over time. Similarly, while most of the countries that adopted inflation as the target for monetary policy have also faced higher output and employment losses during recent episodes of disinflation, the increase in their sacrifice ratios tended to be smaller than for other countries in our sample.

\section{Sacrifice ratios estimated from the aggregate supply curve}

Since the early 1980s, a number of papers have attempted to assess sacrifice ratios and their changes over time from the slope of the aggregate supply curve, derived from the "split" of nominal income changes into changes in real growth and the rate of inflation respectively. For instance, Gordon (1982a) relies on such estimates in analysing the evidence from 14 historical episodes of reducing inflation. The slope of the aggregate supply curve is also used by Hutchison and Walsh (1998), who evaluate the impact on sacrifice ratios of the new monetary policy regime in New Zealand, and by Kiley (1997) in a study of the importance of nominal rigidities in generating business cycles in the United States.

In describing the origins of this method, it is natural to start with Lucas' (1973) model of the output-inflation trade-off. In the long run, this model assumes market clearing and a vertical aggregate 
supply curve at an equilibrium output level $Q^{*}{ }^{9}$ However, due to information problems and expectational errors, actual output may deviate from $Q^{*}$, as each firm $(i)$ will change its output $Q_{i}$ when it perceives its own price $P_{i}$ to deviate from its perception of the general price level $P^{e}$. By aggregating over all firms and allowing for persistence in output deviations, Lucas' model can be written as:

$$
\log \left(Q / Q^{*}\right)_{t}=\beta^{\prime}\left(P_{i, t}-P^{e}\right)+\lambda \log \left(Q / Q^{*}\right)_{t-1} \text { with } \beta^{\prime} \geq 0 \text { and } 0 \leq \lambda \leq 1
$$

In implementing (1), Lucas approximates expectational errors by nominal income or demand changes $(\Delta y)$ and, by using the nominal income identity $(Y=P Q)$, complements the supply function with a price change equation to obtain:

$$
\begin{aligned}
& \log \left(Q / Q^{*}\right)_{t}=\beta\left(\Delta y_{t}\right)+\lambda \log \left(Q / Q^{*}\right)_{t-1} \text { and } \\
& \pi_{t}=(1-\beta) \Delta y_{t}+\beta \Delta y_{t-1}-\lambda \Delta \log \left(Q / Q^{*}\right)_{t-1}
\end{aligned}
$$

Because information problems and expectational errors are likely to be more pronounced in conditions of volatile developments in nominal demand, $\beta$ is expected to be smaller in countries with highly volatile nominal demand changes; that is, in such circumstances the aggregate supply curve will be rather steep, as firms find it difficult to distinguish relative from aggregate price changes and are unlikely to adjust their output in response to changes in nominal demand. Conversely, when nominal demand changes are relatively stable, firms are more responsive to aggregate demand changes and the aggregate supply curve will be rather flat.

While Lucas' estimates of equation (2) confirmed expectations about the influence of the volatility of nominal demand changes, ${ }^{10}$ the notion of sacrifice ratios does not "sit well" with the theoretical assumptions underlying the model. In particular, except for short-run information lags, markets are assumed to clear and the model focuses on output as the dependent variable. Moreover, the corresponding price change or inflation equation has not performed well, suggesting that it might be misspecified. ${ }^{11}$ Indeed, given the well-known persistence of inflation and the various new-Keynesian hypotheses justifying the absence of market-clearing prices and the role of past price developments in explaining today's prices, one missing variable in equation (3) is likely to be lagged rates of inflation. Another source of potential error is the omission of supply shocks, which were assumed to be

The model also assumes that the aggregate demand curve is unit elastic and that shifts in the aggregate supply and demand curves are independent of each other. Although these assumptions may not be valid, they also apply to most of the estimates reported in this paper.

10 The model has also been estimated for other country samples and periods and the results generally confirm the predicted influence of the volatility of nominal demand changes. See for instance Alberro (1981), Christensen and Palsam (1989), Froyen and Waud (1980) and Hess and Shin (1995).

11 As pointed out in Lucas (1976), (2) and (3) do not form a two-equation model as they can both be derived from the nominal income identity. Instead they should be interpreted as alternative ways of writing the same model, with (2) 
independent of price developments in Lucas' formulation, but clearly may bias the underlying parameter estimates of the model if that assumption does not hold.

In light of these concerns, other authors proposed an alternative approach stressing inflation rather than output persistence, dropping the assumption of market clearing and including controls for shifts in the aggregate supply curve. ${ }^{12}$ In particular, Gordon (1981 and 1982b) suggested the following price change equation: ${ }^{13}$

$$
\pi_{t}=\alpha(L) \pi_{t-1}+\theta_{1} \log \left(Q / Q^{*}\right)_{t}+\theta_{2} \Delta \log \left(Q / Q^{*}\right)_{t}+\varphi S_{t} \quad \text { where } L \text { is a polynomial in the lag }
$$
operator and $S$ is a set of controls for supply shocks. Letting $q=\log \left(Q / Q^{*}\right), \Delta q^{*}=\Delta \log Q^{*}$, $\Delta y^{\prime}=\Delta y-\Delta q^{*}$ and using the identity $\pi=\Delta y^{\prime}-\Delta q$, (4) can be rewritten as:

$$
\pi_{t}=\left(1 /\left(1+\theta_{1}+\theta_{2}\right)\right)\left(\alpha(L) \pi_{t-1}+\left(\theta_{1}+\theta_{2}\right) \Delta y_{t}^{\prime}+\theta_{1} q_{t-1}+\phi S_{t}\right)
$$

or, for $\pi$ only entering the right-hand-side with one lag:

$$
\pi_{t}=\alpha(1-\beta) \pi_{t-1}+\beta \Delta y_{t}^{\prime}+\lambda q_{t-1}+\phi S_{t}
$$

where $\beta=\left(\theta_{1}+\theta_{2}\right) /\left(1+\theta_{1}+\theta_{2}\right), \lambda=\theta_{1}(1-\beta)$ and $\phi^{\prime}=\phi(1-\beta)$. Using this version of the model, the new-Keynesian theories have emphasised the role of menu costs in generating a non-vertical short-run aggregate supply function in the sense that sluggish price adjustments associated with costs of adjusting wages or prices lead to a positive short-run relationship between nominal income shocks and real output growth.

In terms of empirical implementation, one key question is which theoretical constraints to impose in estimation. At one extreme, using data on New Zealand, Hutchison and Walsh (1998) estimate an equation of the form:

$$
\pi_{t}=\delta+\beta \Delta y_{t}+\lambda q_{t-1}+\gamma E_{t-1} \pi_{t}+\phi S_{t}+\varepsilon_{t}
$$

which can be viewed as an unconstrained version of (6). Hutchison and Walsh interpret the lagged output gap term in this equation as a correction for cyclical conditions and thus focus on the parameter $\beta$ as a measure of rigidity in the inflation process. ${ }^{14}$ In particular, they calculate the short-run sacrifice

expressed in levels and (3) in first differences. Nonetheless, this does not change the fact that when expressed in first differences, the model does not perform particularly well and seems to be misspecified.

12 In a more recent paper, Chand (1997) proposed jointly estimating an equation for real output growth and an equation for the acceleration in inflation. We report estimates of this specification, including controls for wage and import price shocks, in Annex Table 2.

13 As shown by Chadha et al. (1992) (4) can be derived from: $\pi_{t}=\alpha \pi_{t}^{e}+\lambda^{\prime} \log \left(Q / Q^{*}\right)_{t}+\phi S_{t}$ if we assume that $\pi^{e}$ is a geometrically weighted distribution of lagged rates of inflation.

14 This interpretation can also be viewed in the context of a Phillips curve, with $\beta$ and the sacrifice ratio measured for an economy in a cyclically "neutral" position. 
ratio as $(1-\beta) / \beta$ and thus exclude both the coefficients on the lagged gap and expected inflation from their measure of the trade-off.

Table 2 presents estimates of (7) for the 19 countries in our sample, using lagged inflation as a measure of inflation expectations and the change in relative import prices as a proxy for supply shocks. The first set of columns displays the coefficients estimated with data from 1965 to 1985 and the second set estimates for 1985 to $1998 .^{15}$ Focusing on the first set of columns, the estimates of $\beta$ vary significantly across countries, with the evidence suggesting that the United States and Switzerland have the flattest aggregate supply curves (and thus the highest sacrifice ratios), while Norway, Ireland and Japan have the steepest. What is also striking, however, is the widespread increase in sacrifice ratios implicit in the estimates for the later period. In 16 out of the 19 countries in the sample, the point estimate of $\beta$ is lower in the second period than in the first, suggesting that a larger share of nominal income changes (for instance a change of monetary policy) is now directly reflected in real output growth; as a result, sacrifice ratios have become higher. For this group of countries as a whole, the average sacrifice ratio rises from 1.40 in the earlier period to 3.45 in the later period. Although the estimated change in $\beta$ is only significant at the $10 \%$ level or less in five countries, this table provides a crude indication that there may have been a change in the inflation process as central banks increasingly pursued a price stability objective.

One shortcoming of this unconstrained version of the model is that the definition of the sacrifice ratio used by Hutchison and Walsh and shown in Table 2 is not the only possible alternative. In particular, two specific parts of the model seem open to interpretation. First, the use of lagged inflation in our reformulation of their specification adds another dimension to nominal rigidity by reintroducing the persistence in inflation noted by Gordon. As the coefficient on lagged inflation might also be thought of as a measure of nominal rigidity, it is no longer clear whether $(1-\beta)$ or $\gamma$ should be in the numerator of the sacrifice ratio. ${ }^{16}$ Second, as can be seen in the derivation shown by equations (4)-(6), the coefficient on the change in nominal income implicitly includes not only the slope of the aggregate supply curve $\left(\theta_{1}\right)$, but also $\theta_{2}$, which is the effect on inflation of the change in the output gap (sometimes referred to as a "speed limit" effect). In contrast, using the coefficient on the lagged output gap in Hutchison and Walsh's formulation in the calculation of the sacrifice ratio bases it only on the parameters $\theta_{1}$ and $\alpha$ in the initial equation (4). ${ }^{17}$

15 The 1965 starting point is approximate. For some countries, the sample begins a few years later due to data constraints.

16 Hutchison and Walsh did not include lagged inflation in their specification, but applied a survey-based measure of inflation expectations. Thus, the issue of additional persistence generated by using a lagged inflation term may relate more to our adaptation of their specification than to their implementation of the model.

17 A separate issue is the extent to which a slowdown in nominal demand growth not only affects inflation directly but might also impact prices indirectly by inducing a gradual rise in the output gap. If so, the sacrifice ratios shown in Table 2 may overstate the actual output losses associated with reducing inflation because they exclude this secondary effect on 
The sensitivity of the sacrifice ratio estimates to changes in the precise definition is illustrated in Table 3. As in Table 2, estimates are presented separately for the two periods. In the first column for each period, we calculate the sacrifice ratio as $\gamma / \beta$, thus replacing the estimate of nominal rigidity from the coefficient on nominal income growth $(1-\beta)$ with one based on the coefficient on lagged inflation. The second column in each period also replaces $\beta$ in the denominator with the coefficient on the lagged output gap $(\lambda)$, thus calculating the sacrifice ratio as $\gamma / \lambda$.

Turning first to the estimates that use the coefficient on lagged inflation as a measure of nominal rigidity, the implied sacrifice ratios tend to be lower, on balance, than those shown in Table 2. The differences are quite slight for the earlier sample: the average sacrifice ratio in Table 3 is only a little less than that in Table 2, and both the cross-country correlation coefficient and the rank correlation between the two estimates are above 0.9. In the latter period, however, the differences appear somewhat larger. The average estimated sacrifice ratio drops by more than a third, with country-specific estimates falling in all but two countries (the United States and New Zealand). In addition, the cross-country and rank correlation coefficients fall to 0.8 and 0.65 respectively.

The estimated sacrifice ratios are even more sensitive to the substitution of $\lambda$ for $\beta$ in the denominator of the calculation. Although the average sacrifice ratio for the first period (column 2 of Table 3 ) is nearly identical to its counterpart in Table 2, there are substantial changes in many of the individual country estimates. Reflecting this, the cross-country correlation coefficient falls to 0.25 and the rank correlation is only 0.05 . The same pattern is evident for the latter period, although in this case the average sacrifice ratio also declines (presumably because $\gamma$ is used in the numerator).

Despite these differences in point estimates, the general impression from Table 2 of an increase in sacrifice ratios between the first and second subperiods is still evident in Table 3 . The number of countries for which the aggregate supply curve flattens is a slightly less; 13 or 14 out of 19 rather than the 16 in Table 2. But there are still sizable increases in sacrifice ratios in many of the countries where the coefficients are estimated most precisely.

Nevertheless, it may be desirable to use a specification based on the aggregate supply methodology that eliminates such ambiguities. This is relatively easily accomplished by imposing two additional restrictions. First, by eliminating the influence of the change in the output gap in equation (4), the coefficients on nominal income changes and the lagged output gap are identical. ${ }^{18}$ This version of the

prices. However, we have followed the existing literature in this area and interpreted $\beta$ and $\lambda$ as two alternative, and not as two complementary measures, of the slope of the short-run aggregate supply curve.

18 This simplification can be justified by starting from a simple Phillips curve:

$\pi_{t}=\alpha^{\prime}+\beta^{\prime} q_{t}+\gamma^{\prime} \pi_{t-1}+\phi^{\prime} S_{t}$

and then using the nominal income identity to rewrite the above equation as: 
model lends itself more easily to the calculation of sacrifice ratios, or at the least reduces the set of potential candidates.

In addition, the inclusion of the lagged inflation term brings to the forefront the issue of long-run nominal neutrality. Imposing the homogeneity restriction in the context of equation (4) requires adding the restriction $\alpha=1$ or, in terms of the specification in Table $2, \gamma=(1-\beta)$. Together with the restriction noted above, equation (vi) now becomes:

$$
\pi_{t}=(1-\beta) \pi_{t-1}+\beta \Delta y_{t}+\beta q_{t-1}+\phi S_{t}
$$

and the sacrifice ratio can be uniquely derived as $(1-\beta) / \beta$. In other words, when the homogeneity constraint is satisfied and there is no "speed limit" effect, the sacrifice ratio is proportional to that part of a nominal demand shock that lowers output growth and can be attributed to the nominal rigidities or inflation inertia in the aggregate supply curve.

As we saw in Table 2, the lagged inflation term is highly significant in most countries for both periods. Moreover, the homogeneity constraint is generally satisfied, though there are some exceptions in the more recent period. ${ }^{19}$ This is shown in the first line for each country in Table 4, where we have estimated equation (8), leaving the column for the lagged inflation coefficient empty whenever the constraint $\gamma=(1-\beta)$ is satisfied.

The estimates in Table 4 once again tend to confirm the patterns of change evident in Table 2. In the majority of countries, the sacrifice ratio rises between the first and second periods, with substantial increases evident in some countries. From the unconstrained estimates in Table 2, it also appears that the fall in $\beta$ can mostly be attributed to a lower coefficient on the lagged output gap (i.e. a rise in real rigidity) rather than a rise in the coefficient on the lagged inflation rate (i.e. higher nominal inertia). For the 19 countries on average, $\lambda$ declines from 0.45 to 0.25 from the first to the second period while $\gamma$ only increases from 0.40 to 0.45 .

As regard the size of the sacrifice ratios and their changes over time, the 19 countries can be divided into three groups:

$$
\begin{aligned}
& \pi_{t}=\alpha^{\prime}+\beta^{\prime} q_{t-1}+\beta^{\prime}\left(\Delta y_{t}-\Delta q^{*}-\pi_{t}\right)+\gamma^{\prime} \pi_{t-1}+\phi^{\prime} S_{t} \text { or } \\
& \pi_{t}=\alpha+\beta q_{t-1}+\beta \Delta y_{t}{ }_{t}+\gamma \pi_{t-1}+\phi S_{t}
\end{aligned}
$$

On the additional assumption that the potential rate of growth has been broadly constant, $\beta \Delta q^{*}$ can be subsumed in the intercept term and $\Delta y^{\prime}$ replaced by $\Delta y$, giving equation (8) below.

19

As shown by Andersen (1997), failure to satisfy the homogeneity constraint may indicate another source of inflation inertia, related to the structure of information. Thus, when firms face problems distinguishing between transitory and permanent nominal shocks, they are unlikely to fully adjust their prices to the shocks, so that even transitory shocks will have persistent real effects. The model by Andersen is mostly concerned with exchange rate shocks while the information structure related to a monetary shock is likely to be more clear-cut. 
- those countries that have relatively low sacrifice ratios and have maintained low ratios in both periods. This group would include Italy, Norway (but the estimates are poor) and Spain. New Zealand and Portugal might also be included in this group, although their sacrifice ratios have increased somewhat;

- those countries that have managed to bring down their sacrifice ratios in the more recent period. The Netherlands, Switzerland and Sweden would be in this group. In Sweden and the Netherlands, the decline primarily reflects a decline in nominal inertia, whereas in Switzerland both real rigidity and nominal inertia appear to have fallen;

- the rest of the countries, and thus a large majority, would be in a third group characterised by a significant increase in sacrifice ratios between the first and the second subperiod. The largest increases have occurred in Japan, Germany, Canada, Denmark and Ireland, which have seen their sacrifice ratios increasing from well below or at the mean in the first subperiod to well above the mean in the second. The United States and France are above the mean in both periods, but the distance has widened in the more recent period. In contrast, the United Kingdom, Australia and Finland have experienced large increases, while remaining below the mean. Looking back at the unconstrained coefficient estimates, increases in both real rigidities and nominal inertia contributed to the rise in sacrifice ratios in most of these countries. The exceptions are Canada and the United Kingdom, where a rise in real rigidities played the dominant role, and the United States, where most of the rise in the sacrifice ratio reflects an increase in the already high degree of nominal inertia.

\section{Sacrifice ratios based on wage and price adjustment equations}

In this section we turn to sacrifice ratios calculated from structural wage and price equations. To motivate the interpretation of this approach we begin by considering the simple wage equation:

$$
\Delta w_{t}=\theta-\alpha u_{t}+\phi \Delta p c_{t}+(1-\phi) \Delta w_{t-1}+v_{t}
$$

where $w$ refers to the nominal wage, $p c$ to consumer prices and $u$ to the rate of unemployment (all in $\operatorname{logs}), \theta$ is an intercept term that may capture a real wage target, $\Delta$ is the first difference operator and $\alpha$ and $\phi$ are positive parameters. To keep matters simple, we assume that price changes follow contemporaneous changes in standard unit labour costs:

$$
\Delta p c_{t}=\Delta w_{t}-\mu
$$


where $\mu$ denotes long-term productivity growth. ${ }^{20}$ Thus (9) can be rewritten as:

$$
\Delta \Delta w_{t}=\left(\theta-\phi \mu-\alpha u_{t}+v_{t}\right) /(1-\phi)
$$

If productivity declines $(\Delta \mu<0$, a real shock) and employees do not adjust their real wage target, keeping the inflation rate unchanged would require increasing the unemployment rate to a level that is sufficiently high to offset the upward pressure on prices. Even if the shock is only temporary and unemployment eventually returns to its initial level, ${ }^{21}$ the economy would suffer a loss equivalent to the cumulative rise in unemployment in the intermediate period, which can be measured as:

$$
\sum_{t} \Delta u_{t}=(\phi / \alpha)\left(\Delta \mu_{t}\right)
$$

The ratio $\phi / \alpha$ is the definition of real rigidity proposed by Grubb et al. (1983), and it depends on two parameters: the sensitivity of wage changes to the rate of unemployment $(\alpha)$ and the extent to which contemporaneous price changes are reflected in wages $(\phi)$. Although it may be reasonable to assume that the size of $\phi$ affects the degree of real rigidity, note that this definition is sensitive to the specification used in (9). For instance, if we changed (9) to:

$$
\Delta w_{t}=\theta-\alpha u_{t}+\phi \Delta p c_{t}+(1-\phi) \Delta p c_{t-1}
$$

real rigidity would simply be $1 / \alpha$, the inverse of the coefficient on the unemployment rate. ${ }^{22}$

From (11) it can also be seen that if the government wants to reduce the rate of inflation by 1 percentage point (a nominal shock), $u$ would again need to rise and stay at a higher level until inflation has come down, after which it would return to the initial level. ${ }^{23}$ As for a real shock, the cumulative rise in $u$ can be calculated as:

$$
\sum_{t} \Delta u_{t}=((1-\phi) / \alpha)(\Delta \pi)
$$

Given the nature of the shock, the ratio $(1-\phi) / \alpha$ might be defined as the nominal rigidity and it obviously depends on the same parameters as the real rigidity. The difference is simply that a rapid pass-through of price changes into wages makes the inflation process less rigid in response to nominal shocks. Note also that (13) corresponds to most definitions of the sacrifice ratio and is similar to those

20

Since terms-of-trade shifts have similar effects on equilibrium real wages as changes in productivity growth, we can think of $\mu$ as productivity growth augmented by (or corrected for) terms-of-trade shifts.

21 To do so, the rate of unemployment needs to be a stationary variable, a condition that most countries do not meet (see Annex Table 1).

22 Another alternative might be to introduce a productivity term in equation (9) to allow real wage aspirations to respond somewhat to changes in long-run productivity growth. For specifications of this type, see Braun (1987) and Blanchard and Katz (1997).

23 In the following we do not distinguish between wage and price shocks, even though the short-run dynamics of such shocks may differ. For further discussion, see Andersen (1987). 
derived in the previous section. Again, however, it requires only a small respecification to get a different result. For instance, if we maintain (9), but change the price equation (10) to:

$$
\Delta p c_{t}=\Delta w_{t-1}-\mu
$$

and substitute $\left(10^{\prime}\right)$ into (9), the definition of nominal rigidity would reduce to $1 / \alpha$, i.e. it becomes identical to the real wage rigidity. ${ }^{24}$

This model can be easily extended to allow for other sources of rigidity or variability in the system. For example, instead of a model with wage rigidity and flexible price setting, as in equations (9) and (10), we can introduce rigid price setting by adding an inertia term into the mark-up equation:

$$
\Delta p c_{t}=\delta \Delta w_{t}+(1-\delta) \Delta w_{t-1}-\mu
$$

Substituting (14) into (9) gives:

$$
\Delta \Delta w_{t}=\left(\theta-\phi \mu-\alpha u_{t}+v_{\mathrm{t}}\right) /(1-\phi \delta)
$$

instead of (11). The unemployment response to a real shock (holding inflation constant) is unchanged from (12) under this formulation, because real rigidities only exist in the labour market. However, the unemployment response to a nominal shock (e.g. a conscious effort to reduce nominal wage inflation) now becomes:

$$
\sum_{t} \Delta u_{t}=((1-\phi \delta) / \alpha)(-\Delta \Delta w)
$$

In other words, if we interpret (16) as a sacrifice ratio, we need to take account of nominal inertia in both the wage and the price equation. ${ }^{25}$

A second extension is to introduce business cycle variation into the mark-up equation by assuming that the ability of producers to pass on higher labour costs depends on the tightness of product markets. ${ }^{26}$ Maintaining the inertia introduced in equation (14), this added assumption leads to:

$$
\Delta p c_{t}=-\mu+\delta \Delta w_{t}+(1-\delta) \Delta w_{t-1}+\beta g a p_{t}
$$

where gap is the output gap and related to the unemployment rate through a simple Okun equation:

$$
U_{t}-U^{*}=-\lambda g a p_{t}
$$

24

This somewhat artificial specification might best be characterised as complete nominal inertia, as the coefficient on the lagged wage term is unity.

25

One could also consider the case with lagged price changes and lagged wage changes in the wage equation. However, because the lagged unemployment rate then enters the reduced-form wage equation, the expressions become more complicated to interpret and less helpful for illustrating the influence of nominal inertia and real rigidities on the sacrifice ratios.

26 The behaviour of the mark-up is one of main sources of inertia in the new structural models of the Phillips curve (Gali and Gertler (1998)). Thus, the mark-up not only depends on the output gap, but responds with a considerable lag to changes in the output gap. 
where $U^{*}$ is the equilibrium rate of unemployment. After some manipulations, (9), (17) and (18) can be combined to yield:

$$
\Delta \Delta w_{t}=\left(\theta-\phi(\beta / \lambda) U^{*}-\phi \mu-\alpha u_{t}-\phi(\beta / \lambda) U_{t}+v_{t}\right) /(1-\phi \delta)
$$

Under this specification, the measures of real and nominal rigidity both change to reflect the influence of product market tightness. In particular, the response to a real productivity shock is now:

$$
\sum_{t} \Delta U_{t}=(\phi /((\alpha / \bar{U})+\phi(\beta / \lambda)))(-\Delta \mu)
$$

while the response to a nominal shock becomes:

$$
\sum_{t} \Delta U_{t}=((1-\phi \delta) /((\alpha / \bar{U})+\phi(\beta / \lambda)))(-\Delta \Delta w)
$$

Compared with the previous results, (20) and (21) imply that the concept of real rigidity should be extended to include the reaction of prices to changes in the output gap as well as the parameter of the Okun equation, whereas the influence of nominal inertia continues to be inversely related to the magnitude of contemporaneous responses in both the price and wage equations. ${ }^{27}$

Although the preceding examples obviously do not comprise all the empirical models that could be specified, they are sufficient to illustrate the principal parameters affecting sacrifice ratios. Thus, in the empirical analysis that follows, we have focused our specifications of the wage and price equations in a way that brings out the real rigidities and nominal inertia inherent in the previous discussion. To that end, our specification of the wage equation includes both lagged wages and lagged prices as well as the level and change of the unemployment rate. The price equation also includes lags of wages and prices, uses the output gap rather than the unemployment rate and adds in the change in import prices as a proxy for supply shocks. We then calculate sacrifice ratios for each equation separately, as well as from parameters of the system as a whole. The sacrifice ratio from the wage equation can be interpreted as an approximation to equation (13), while that from the price equation is an approximation to a parallel model with sticky prices and flexible wages. Calculating the combined sacrifice ratio, which allows for rigidities in both the wage and price equations and is similar in spirit to equation (21), also requires estimating an Okun's law relationship for each country. This parameter is shown in Annex Table 3.

For each equation we have made two estimates: one for the full sample period (in most cases 1965-98) and a second one in which we truncate the sample period in 1990. This allows us to evaluate

27 The introduction of the Okun equation, which is usually expressed in terms of the actual rather than the log rate of unemployment, requires us to combine equations written in logs and levels. While thus far we have, for convenience, expressed the sacrifice ratio in this section in terms of log changes in the rate of unemployment, the measures of real and nominal rigidity in (20) and (21) are expressed in terms of changes in the actual rate of unemployment, while $\bar{U}$ indicates the average rate of unemployment over the period of interest. 
whether the lower rates of inflation in the 1990s influenced the dynamics of wage and price behaviour in three ways. First, we test the stability of the parameters using standard $\chi^{2}$ tests. Second, we generate forecasts for the 1990s using the equations for the shorter period and analyse the size and pattern of forecast errors. Third, we compare the sacrifice ratios for the two sets of parameter estimates.

Turning first to the wage equations (Table 5), the strongest case for a behavioural change is the United Kingdom. The p-value of the structural stability test (Table 7) is less than 0.1 and, perhaps more compelling, the equation estimated over the shorter sample period greatly overpredicts actual wage changes in the 1990s. The main reason for the break seems to be an increase in the 1990s in the sensitivity of nominal wages to the rate of unemployment, which produces a sharp drop in the estimated sacrifice ratio based on this model. ${ }^{28}$ The tests for structural breaks also point to the United States and Japan as countries experiencing a structural change in the 1990s. However, due to offsetting shifts in other parameters, the estimated sacrifice ratios do not change very much and out-of-sample forecasts do not appear to be biased, although the RMSE for Japan is rather high).

Focusing more on the forecast errors, there is evidence of parameter instability in a number of other countries. For example, the wage equation for Italy tends to overpredict actual wage developments in the 1990s, perhaps reflecting the 1992 incomes policy agreement. ${ }^{29}$ In contrast, the wage equations for Australia, Finland and Sweden greatly underpredict wage inflation over the past decade. In all three countries, the parameter estimates point to a significant increase in real rigidities, as the coefficients on the rate of unemployment fall sharply in absolute value and in Australia and Sweden the coefficient on the change in unemployment increases as well indicating a higher degree of hysteresis. In addition, there is some evidence of an increase in nominal rigidity in each of these countries. Smaller, although still sizable, positive forecast errors are also evident in Denmark, Norway and Spain and in each case appear to reflect increases in both nominal and real wage rigidities.

With regards to the sacrifice ratios derived from the parameter estimates of the wage equation, 11 of the 19 countries in our sample show an increase in the sacrifice ratio in the 1990s. However, the magnitude of the change is economically meaningful in only six of these and for the 19 countries as a group the sacrifice ratio remained stable. The largest increases are evident in Australia and Sweden, two countries that introduced inflation targets during the past decade. Sizable increases in sacrifice ratios also appear for Denmark, Finland and Spain. The largest declines occurred in the United Kingdom (as mentioned earlier) and Germany. Most other countries exhibited little change in sacrifice ratios over the sample period although, as before, there is significant variation in the level of the

Because the coefficient on contemporaneous price changes exceeds unity, we measured the sacrifice ratio using average nominal inertia for the other countries in the sample. A similar problem was encountered for Australia.

29 Despite the abolition of ex post wage indexation, this behavioural change appears as a decline in real rigidity rather than as a decline in inflation inertia. 
sacrifice ratio across countries, with Japan, Italy and Portugal at the low end of the spectrum and New Zealand, Denmark and Switzerland at the high end.

The sacrifice ratios derived from the consumer price equations (displayed in Table 6) tend to be higher than those based on the wage equations. This is not surprising given that, for most countries, the Okun coefficients tend to be below unity (Annex Table 3). As regards the evidence on behavioural shifts, only Canada, Sweden and Switzerland show clear signs of a structural break in the chi-square tests. In Canada and Sweden, this "break" appears to reflect a reduction in both real and nominal rigidities, the combination of which leads to a substantial decline in the sacrifice ratio and an overprediction of price inflation in the 1990s. In Switzerland, on the other hand, a marked rise in inflation inertia is the main reason for the higher sacrifice ratio and the smaller impact of contemporaneous wage growth also contributes to price inflation being underpredicted by a cumulative $8 \%$ this decade.

It is perhaps noteworthy that, except for the United Kingdom, the consumer price equations tend to overpredict price inflation in the countries that adopted inflation targets at the beginning of this decade. Thus, in addition to Canada and Sweden, there are sizable forecast errors for New Zealand, despite an apparent increase in real rigidities. With respect to the United Kingdom, the tendency for the model to underpredict reflects some rise in real rigidities (in contrast to the estimates for wages), but is predominantly due to a rise in the intercept term. Spain has also seen a rise in real rigidities in the product market, but this has been more than offset by a downward shift of the intercept term.

It is also interesting to note that in many countries the forecast errors in the wage and price equations are of opposite sign. In the majority of cases with relatively large errors, the wage equation typically underpredicts wage growth while the price equation overpredicts inflation. One potential explanation for this result is that there has been a pickup in underlying productivity growth in countries exhibiting this pattern. Separate data on productivity growth support this explanation in Australia and in the Scandinavian countries; similarly, in the United Kingdom, the reverse result (overprediction of wage growth and an underprediction of inflation) has been accompanied by slower productivity growth in the 1990s. The pattern of errors in Italy and Canada cannot be attributed to productivity performance, but rather seems to reflect changes in firms' mark-ups (higher in Italy and lower in Canada).

By combining the estimated parameters from the wage and price equations (along with the Okun coefficients shown in Annex Table 3), we can construct sacrifice ratios based on equation (21). These are shown in Table 8. For our sample as a whole, there are two noteworthy aspects to these estimates. First, the variation in the estimated sacrifice ratios across countries narrows considerably when the wage and price equations are used together. For the entire sample period, the estimates range from 0.3 to 2.8, but only the United Kingdom is above 2.5. Second, and perhaps related to this, the changes in sacrifice ratios are much more modest when the parameters from both equations are used. Although, as before, the majority of countries show an increase in the sacrifice ratio in the 1990s, the largest 
increase is only 0.9 (Spain), and only three other countries (Ireland, Sweden and Australia) have an increase of 0.4 or more. Thus, the sacrifice ratios constructed from these structural models do not lend much support to the hypothesis that the decline in inflation in the 1990s significantly increased nominal and real rigidities and thus the costs of disinflation.

\section{Sacrifice ratios during episodes of disinflation}

An alternative approach to the econometrics-based methods described in the preceding sections has been to calculate sacrifice ratios directly from various episodes of disinflation. Basically, this episode-specific method involves determining the endpoints of each episode through inspection of changes in inflation rates, and then calculating sacrifice ratios over each predefined episode based on assumptions about unemployment or output gaps. Mankiw (1991), for example, uses this approach to calculate a sacrifice ratio for the US disinflation of the early 1980s. Ball (1994) applies a similar approach to derive sacrifice ratios for a number of countries by assuming that the output gap is zero at the onset of a disinflation episode and again four quarters after the end of each episode. Andersen (1992), on the other hand, uses only observed changes in inflation, output and unemployment rates and thus refrains from making country-specific assumptions about the natural rate of unemployment and the growth rate of potential output. ${ }^{30}$

Critics of this approach cite three important shortcomings. ${ }^{31}$ First, the method considers only periods of disinflation and thus ignores potentially important correlations between unemployment or output growth and inflation changes at other points in the business cycle. ${ }^{32}$ Second, the method assumes that each disinflationary episode is generated by a monetary policy shock. If, for example, aggregate supply shocks are an important source of variation in output and inflation, then sacrifice ratios derived from actual developments may be difficult to interpret without auxiliary information on such shocks. Third, given the nature of the calculations, variations in sacrifice ratios over time or across countries are difficult to explain on analytical grounds and attempts to uncover correlations with specific factors,

30

This is, of course, not the same thing as calculating sacrifice ratios that are free from assumptions about unemployment or output gaps. Using the cumulative change in unemployment or the output gap implicitly assumes that both the rate of unemployment and real output were at their natural levels at the onset of the disinflationary period. If this assumption does not hold and disinflation starts in a year of excess supply (excess demand), the sacrifice ratio will be understated (overstated). On the other hand, this simpler approach has the advantage that it can be applied systematically to all episodes in the sample.

31 See, for example, Cecchetti (1994).

32 Ball (1994) considers this to be an advantage of the episode-specific approach, as it allows the sacrifice ratio during disinflations to be different from that during temporary fluctuations in demand and to vary across different business cycles. As noted earlier, Jordan (1997) calculates both sacrifice ratios for periods of disinflation and benefit ratios for periods of accelerating inflation and finds them to differ significantly. 
such as the degree of disinflation or the presence of nominal and real rigidities, have mostly been inconclusive.

In our application of this procedure, we follow Ball (1994) and date inflation peaks (troughs) as years in which the rate of inflation was higher (lower) than in both the preceding and the following year, with the cumulative disinflation $(\Delta \pi)$ measured as the change in the rate of inflation between peaks and troughs. Using annual data for personal consumption deflators as the measure of inflation, we found two episodes of disinflation per country. ${ }^{33}$ The output or employment losses during these periods of disinflation were calculated as the cumulative rise in the output gap and the rate of unemployment respectively, with no specific assumptions made as to the levels of the output and unemployment gaps at the time of the inflation peak. ${ }^{34}$

As can be seen in Table 9, the disinflation episodes of the 1980s started from initial rates of inflation averaging about $13 \frac{1}{2} \%$, while the rate of disinflation averaged almost 10 percentage points over five years. In contrast, the disinflation episodes of the 1990s started from initial rates that, on average, were only half as high as in the 1980s. The degree of disinflation was also much smaller and the length of the disinflationary period was somewhat more protracted in most countries. As a result, while the average speed of disinflation was almost 2 percentage points per year in the 1980s, it was less than one percentage point per year in the 1990s.

Four points are worth highlighting regarding the sacrifice ratios:

(i) the average figures provide some suggestive evidence that lower initial rates of inflation and slower rates of disinflation are associated with higher sacrifice ratios. However, cross-country regressions for both the 1980s and the 1990s, as well as for changes in sacrifice ratios between the two periods, provided no conclusive evidence;

(ii) despite marked differences in the dynamic properties of the output gap and the rate of unemployment (Annex Table 1), the two "loss measures" provide relatively similar estimates of the variation in sacrifice ratios across countries. For the 1980s, the cross-country correlation is 0.55 , rising to 0.90 for the 1990 s. Moreover, the cross-country correlation of changes in the two measures was almost 0.80 ;

(iii) while the sacrifice ratios measured in terms of unemployment mostly exceed those based on the output gap for the episodes of the 1980s, the gap-based measures tend to be higher for the

33 For Canada and Australia, we used the GDP deflator because consumption deflators gave an unclear dating of the disinflation episodes and, in the case of Canada, were distorted by the introduction of the GST in 1991. Note also that, for those cases in which the second episode "ends" in 1998, the estimates are subject to additional uncertainty because actual outcomes for 1999 are not yet known.

34 For most countries, the output gap was taken from OECD files (see OECD (1997) for a description of the methodology). For Portugal and Switzerland, we calculated our own estimates of the output gap as the OECD data implied that inflation peaked when the economies were in a trough. 
1990s. One reason for this "reversal" might be that some countries, particularly those in Europe, experienced a trend rise in unemployment during the 1980s, which has frequently been attributed to the interaction of disinflationary policies during the early 1980s with persistencecreating structural and institutional factors (hysteresis). ${ }^{35}$ By contrast, in the 1990s, several countries began to deregulate their labour markets, attenuating the rise in unemployment associated with tighter fiscal and monetary policies and, in some cases, allowing the rates of both unemployment and inflation to fall. This reversal is particularly noticeable in the Netherlands and Ireland, where unemployment-based sacrifice ratios came down sharply despite higher sacrifice ratios calculated from the output gap. However, the pattern of relatively large output losses is also evident in countries such as Germany, Spain, New Zealand and Canada, where both estimates of sacrifice ratios rose between the 1980s and the 1990s. In contrast, in the United Kingdom both loss measures seem to be have been favourably affected by a greater influence of market forces. It is also notable that the unemployment-based loss measure changed little for the United States whereas the gap-based measure more than doubled in the 1990s. This seems inconsistent with other evidence of increasing product market competition and raises the possibility that, given an Okun coefficient of 2 to 2.5, the gap-based measure for the $1980 \mathrm{~s}$ is understated; ${ }^{36}$

(iv) several countries have experienced a marked rise in sacrifice ratios between the first and the second episode of disinflation. This is particularly notable in the four largest continental European countries, but is also observed for Canada, Belgium, the four Nordic countries and Switzerland. For Finland, Norway and Sweden, this development is likely to reflect the repercussions of the corrections of the asset price "bubble" of the late 1980s. For some of the other countries, the absence of labour and product market reforms may have played a role. ${ }^{37}$

35 See Ball (1996), who, using a cross-country regression (20 OECD countries), finds that about two-thirds of the rise in the NAIRUs during the 1980 s can be attributed to the interaction between disinflation and labour market imperfections, as proxied by the length of unemployment benefits. Needless to say, if disinflation leads to a permanent rise in unemployment, the employment loss is infinite and the notion of a sacrifice ratio is no longer meaningful.

36 Ball (1994) calculates a sacrifice ratio of 1.8 using quarterly data from 1980:1 to 1983:4, while Mankiw (1991) puts the sacrifice ratio at 2.8 over the period 1981-85. See also Gordon (1999b), who points to the decline in both price inflation and the rate of unemployment as one of the surprises of the 1990s.

An additional explanation might be that fiscal policy was much tighter during the 1990s due to the Maastricht criteria (Gordon (1999)) and more general attempts to make budget balances sustainable. However, when we included changes in structural imbalances in the cross-country regressions we found no significant influence. In fact, developments for individual countries suggest that confidence effects associated with the firmer fiscal stance may have alleviated the output and employment losses. 


\section{Inflation, central bank independence and sacrifice ratios}

Except perhaps for the estimates based on the structural models, the preceding sections provide clear evidence that sacrifice ratios have tended to increase and that these increases are related to changes in inflation inertia and real rigidities in product and labour markets. However, a far more difficult empirical and analytical issue is to determine the extent to which these developments can be directly related to changes in the rate of inflation itself and/or to institutional developments in the area of monetary policy-making.

Although there is no clear consensus, three somewhat contradictory findings have emerged from several papers that have recently addressed this issue. First, over the last two to three decades, countries with highly independent central banks seem to have achieved significantly lower rates of inflation than countries with less independent central banks; in contrast, the degree of independence does not seem to be correlated with average real growth or the rate of unemployment. Second, when taking measures to reduce inflation, countries with highly independent central banks have generally incurred higher output and employment losses than countries with less independent central banks. ${ }^{38}$ Third, countries that disinflate from high initial rates of inflation seem to suffer lower output and employment losses and to have steeper aggregate supply curves than countries which start the process of disinflation from a low initial rate of inflation.

One way to reconcile these findings would be to assume that a high degree of independence shifts the output-inflation trade-off, or the Phillips curve, inwards while, at the same time, flattening it (Walsh (1995)). It could also be argued (and there is some evidence supporting this view) that since central bank independence is associated with low inflation, it is the latter rather than independence that leads to the flatter aggregate supply curve and the higher sacrifice ratio (Jordan (1997)). Finally, if contract length or the degree of indexation is endogenous, the optimal degree of inertia and the optimal monetary policy are determined jointly through the strategic interactions between private agents and the monetary authorities. This process has several potential outcomes, one of which is that, with the central bank more firmly committed to price stability, agents opt for longer contracts so that nominal inertia increases (see Walsh (1995)).

However, this still leaves open the question as to why central bank independence and, presumably, higher credibility does not encourage the more rapid adjustment of inflation expectations to the announcement of policy changes and thus produce lower sacrifice ratios. ${ }^{39}$ Similarly, in the structural In particular, Fuhrer (1997) only finds a statistically significant and positive relationship between central bank independence and the costs of disinflation and no benefits in terms of lower inflation.

39

Indeed, according to Ball's (1992) measure, the sacrifice ratio is inversely proportional to the degree of credibility, and in the simulations reported in Chadha et al. (1992) more credible policies are associated with lower sacrifice ratios. In addition, using an AR model for consumer price inflation and the coefficients on lagged inflation as a measure of 
model of inflation in Gali and Gertler (1998), one would expect the forward-looking component in firms' pricing decision to increase and thus the degree of nominal inertia to decline. It is also puzzling (Posen (1998)) that, even when controlling for nominal wage rigidities, independence still increases sacrifice ratios and that the empirical evidence does not support the postulated positive link between independence and nominal rigidities. Bleaney (1996) is also unable to identify any relationship between central bank independence and various measures of wage-bargaining structures while Walsh (1995) actually finds that high initial rates of inflation reduce sacrifice ratios in the EU countries, once the negative effect of independence is allowed for.

For several reasons, we shall not attempt to resolve the dispute about the possible effects of central bank independence on sacrifice ratios in this paper. ${ }^{40}$ Rather, the purpose of this section is to address the question of whether the rise in real and nominal rigidities, or the flattening of the aggregate supply curves, can be linked to the decline in inflation itself. In particular, Ball et al. (1988) postulate that the slope of the aggregate supply curve may be related to the rate of inflation rather than to the variability of nominal demand changes as assumed by Lucas. Using a menu cost model, they argue that in periods of low inflation the degree of nominal inertia is likely to increase as the interval between price changes by individual firms tends to lengthen. They implement this hypothesis by first estimating equation (2) above for more than 40 countries and then testing whether the country-specific coefficients on nominal demand changes are correlated with cross-country variations in average rates of inflation and the variability of nominal demand shocks. Their results suggest that the rate of inflation directly affects the slope of the aggregate supply curve whereas the variability of nominal demand has only a marginal influence, a finding that has subsequently been confirmed on more recent data by Chapple and Yates (1996).

In testing the possible link between changes in inflation and the size of sacrifice ratios, we proceeded in two steps. First, we ran various cross-country regressions to see whether initial rates of inflation and the amount of disinflation during various episodes had any affect on the parameters and sacrifice ratios reported in the previous sections. As already noted, initial rates of inflation and rates of disinflation do not seem to affect the sacrifice ratios presented in Table 9 and in most other cases we were also unable to identify any significant inflation effects. However, for the $\beta$-coefficients shown in Tables 2 and 4

persistence, Alogoskoufos and Smith (1991), Anderton (1997) and Burdekin and Siklos (1999) all find that shifts towards less accommodating monetary and exchange rate policies tend to coincide with significant declines in the degree of inflation persistence. In Annex Table 4 we show supplementary results using AR equations for the 19 countries in our sample. The evidence supports other results in the literature that estimates of persistence have a positive bias when the mean rate of inflation declines over the sample period. However, since significant coefficients were never obtained when intercept as well as slope shifts were included, it is uncertain whether the lower degree of persistence applies to the whole period or only to $1985-98$.

40 In particular, existing measures of central bank independence do not take account of recent de jure and de facto changes in the degree of central bank independence and thus are of dubious quality. In addition, and perhaps more importantly, the move towards very low rates of inflation has been a global phenomenon, occurring almost independently of the degree of autonomy of individual central banks. 
we found significant evidence of positive inflation effects, both for each subperiod and for changes between the periods. In other words, it does appear that when the initial rate of inflation is low, the aggregate supply curve tends to be rather flat and the sacrifice ratios high.

As a related test, we estimated the following equation used by Ball et al. on our sample:

$$
\beta_{i}=\alpha+\eta \pi_{i}+\kappa \sigma(\Delta y)_{i}+\varepsilon_{i} \quad i=1, \ldots, 19
$$

where the dependent variable is the coefficient on nominal income changes in the unconstrained price adjustment equations in Table 2 and the coefficients on the independent variables (the rate of inflation and the variability of nominal income changes) measure the extent to which cross-country variations in $\beta$ can be attributed to cross-country variations in average inflation and the variability of nominal demand changes respectively. In order to make use of the additional variation we obtained by splitting the sample period in Table 2, we stacked the data for the first and second periods of our sample and treated them as separate observations. As can be seen from Table 10, countries/periods with a relatively low average rate of inflation seem to be facing a flatter supply curve and thus a less favourable trade-off than countries/periods with a higher rate of inflation. The evidence is strongest when the individual country variation across periods is included and when the equation is estimated in changes, but this relationship is also apparent (at least in the early sample period) when only the cross-country variation is used. The coefficients indicate that a five-percentage point decline in the rate of inflation (as occurred, on average, between the two sample periods) would increase the coefficient on the change in nominal GDP by between 0.15 and 0.45 . In contrast, the variability of nominal demand changes does not affect the slope of the supply curve, once inflation is allowed for. ${ }^{41}$

As a second approach, we entered the lagged rate of inflation interacted with both nominal income changes and the lagged output gap by estimating the following equation over the full sample period for each of the 19 countries: ${ }^{42}$

$$
\pi_{t}=\alpha+\beta \Delta y_{t}+\beta^{\prime}\left(1 / \pi_{t-1}\right) \Delta y_{t}+\lambda g a p_{t-1}+\lambda^{\prime}\left(1 / \pi_{t-1}\right) g a p_{t-1}+\gamma \pi_{t-1}+\phi(\Delta p m-\pi)_{t-1}+\varepsilon_{t}
$$

If the hypothesis that lower inflation flattens the aggregate supply curve is valid, we would expect both $\lambda^{\prime}$ and $\beta^{\prime}$ (or the joint coefficient when the constraint $\beta=\lambda$ is satisfied; cf. the note to Table 4 ) to be negative and significant.

41

It should be noted that the rate of inflation and the variability of nominal income changes are highly correlated, which makes it difficult to separate the two effects. We also tested the Ball et al. model using the variability of real output growth as the dependent variable. According to the theory, countries with relatively low inflation and flat aggregate supply curves should, given the variability of nominal income changes, experience comparatively high variability of output growth. However, this prediction was not confirmed by our sample.

42

Since the lagged rate of inflation enters equation (ii) both interactively and as a separate term, we suppressed the latter whenever $\gamma$ was insignificant. Asai (1999) also uses a time-series testing procedure and the tests support the cross-country results. 
As can be seen from the estimation results (Table 11) there is some support for this hypothesis. While there is relatively little change in the coefficients between the 1970s and the 1980s, the marked reduction of inflation in the 1990s significantly flattens the aggregate supply curves. On average, the coefficients on nominal income changes fall by one-third, compared with their levels of the previous decade, and those on the output gap by more than one-half. However, in some cases, where the combined coefficients become negative (France, Canada, Denmark, Norway and Sweden), the coefficients on the interaction terms, as well as the implied flattening of the aggregate supply curves in the 1990s, may be overstated. It should also be noted that, even for countries with highly significant coefficients for $\beta^{\prime}$ and/or $\lambda^{\prime}$, it is unclear whether we have identified a change in behaviour or merely a highly non-linear trade-off curve.

\section{Comparison of the estimated sacrifice ratios}

Before turning to possible policy implications, it is useful to look at the extent to which the various estimates of sacrifice ratios provide consistent messages. From the summary in Tables $12 \mathrm{a}$ and $12 \mathrm{~b},{ }^{43}$ one clear message is that, with one exception, all measures point to a rise in sacrifice ratios from the 1980 s to the 1990s. On average, as rates of inflation have fallen by about one-half, sacrifice ratios have increased by $75 \%$.

It is also evident that the overall rise in sacrifice ratios has been accompanied by a significant change in the ranking of countries (shown in the last column of Tables 12a and 12b). The rank correlation for the two periods is only 0.15 and regressing average sacrifice ratios for the second period on those for the first yields a correlation coefficient of only 0.20 (Table 13). The major changes in relative sacrifice ratios from the first to the second period can be observed for Japan which moved from the 1st to the 14th place, Ireland (2nd to 16th), Finland (7th to 17th), France (11th to 19th) and the Netherlands and Switzerland, which improved their ranking from respectively 17th to 8th and 19th to 10th. Both the United States and Germany continued to have relatively high sacrifice ratios, while those for Portugal, Norway and Sweden have remained relatively low. It is also worth noting that, with the exception of Finland, all the countries which adopted inflation targets this decade have managed to reduce their relative sacrifice ratios and improve their ranking.

At the same time, assessments of countries' performance based on changes in the average sacrifice ratios should be made cautiously. As the tables also show, the standard errors, both between different sacrifice ratios for a given country and across the 19 countries for a given ratio, have almost doubled

43 In order to have sacrifice ratios that are also corrected for wage shocks, we included the estimates from Annex Table 2 in these summary tables. 
between the two periods. Moreover, the sacrifice ratios differ considerably both in their ranking of the 19 countries in a given period or episode and in their evaluation of rank changes between periods. This is evident from the relatively low bilateral correlations for the two periods (Table 13) and for changes between the periods (Table 14).

In particular, the correlations drop considerably when comparing sacrifice ratios across the three estimation methods commonly used in the literature. These differences are shown even more clearly in Table 15, where countries are ranked according to average sacrifice ratios from each of the three methods of estimation. As is evident from the table, the low overall ranking for the United States can mainly be attributed to the flat aggregate supply curve estimated using the approach described in Section 2. In contrast, sacrifice ratios derived from the structural estimates and actual developments place the United States in the upper half of the sample. Japan receives a high rank when assessed from structural estimates and is somewhere in the middle when actual developments are used; however, a significant flattening of the aggregate supply is also evident between the two periods, which accounts for the significant change in Japan's overall ranking. Germany is placed near the bottom independently of the method used, while in the case of France the structural estimates give a relatively favourable ranking, in contrast to the other two which put France near the bottom of the scale. Italy performs well according to both the aggregate supply curve and the structural estimates but receives a low rank when the sacrifice ratio is calculated from actual developments. A striking feature of the measures for the United Kingdom is the persistently low ranking from the structural estimates despite the increase in labour market flexibility. The improvement in the overall ranking is entirely due to the lower sacrifice ratios derived from actual developments, possibly suggesting that the structurally based measures are too insensitive to market reforms. ${ }^{44}$ In contrast, the overall improvement found for Canada is entirely due to the reduction in rigidity captured in the structurally based estimates; sacrifice ratios derived from actual developments place Canada near the bottom of the scale and imply a significant worsening from the 1980s to the 1990s.

Turning to the smaller countries in the sample, Australia and Denmark are similar to the United Kingdom in that they both receive a low ranking from the structurally based estimates but a relatively favourable one from actual developments. Indeed, one notable feature of studies assessing the performance of countries with inflation targeting (Debelle (1996) and Bernanke et al. (1999)) is that they contrast Australia's low sacrifice ratio with those for Canada and New Zealand; our results tend to make this argument less compelling. Belgium's overall rank changed little, as an improvement in actual developments has largely been offset by a flattening of the aggregate supply curve. This pattern is even more pronounced for Ireland, which moves from 1st to 17th place according to the sacrifice

44 Recall that, for the United Kingdom and Australia, the wage equation for both countries implied zero or even negative nominal inertia and that, when calculating the sacrifice ratios, we used the average value for the other 17 countries. This suggests that the structurally based sacrifice ratios for these countries are problematic. 
ratios based on the aggregate supply curve and from 13th to 5th when actual developments are used. In contrast, the overall ranking of Finland has deteriorated sharply as a result of the steep rise in unemployment during the 1990s, while the Netherlands has improved its standing according to all three measures. For New Zealand, two out of three assign a higher rank. In absolute terms, the rise in the sacrifice ratio derived from the aggregate supply curve is somewhat smaller than that found by Hutchison and Walsh (1998), while the output gap-based measure is fairly close to that in Debelle (1997). The overall stable rank for Norway conceals rather divergent trends in individual measures, notably a marked steepening of the aggregate supply curve; however, the low quality of the estimates in general suggests caution in interpreting the estimates for this country. Portugal and Spain display sharp differences with respect to both overall performance and movements in individual ratios. Portugal maintained its already favourable ranking according to two of the three approaches and improved its ranking in the other. Spain, by contrast, remained near the bottom of the scale, as a deterioration in the structural measures reinforced the low rank derived from actual developments. Sweden and Switzerland owe their overall improvement to a steeper aggregate supply curve, which has more than offset less favourable sacrifice ratios derived from actual developments and, in the case of Sweden, a rise in real labour market rigidity.

A related issue concerns the consistency of the information content provided by individual sacrifice ratios within each general approach. From the correlations in Tables 13 and 14 it appears that the measures derived from the slope of the aggregate supply curve are internally consistent and relatively stable for each period. Most of the bilateral correlations are in the $0.60-0.90$ range and the rank correlations are between 0.60 and 0.85 . Moreover, these measures also exhibit relatively high correlations for changes in sacrifice ratios across the two periods.

The sacrifice ratios derived from structural estimates of the wage and price equation $\left(\mathrm{SR}_{w}\right)$ and $\left(\mathrm{SR}_{p c}\right)$ are more problematic, as they appear sensitive to whether labour or product market data are used to generate the estimates. In particular, the correlation between the sacrifice ratios constructed from the wage equation and those constructed from the price equation are negative in both periods, as is the correlation of the changes over time implied by the two methods. This indicates that the estimated costs of disinflation can differ widely, depending on whether labour or product market data are used. To some extent, the ratios derived from combining the parameters of the wage and price equations $\left(\mathrm{SR}_{r f}\right)$ overcome these problems. The correlations between this measure and the ratios based on the wage or price equation alone are positive and relatively high, as are the estimates of the change. However, like the other structurally based ratios, those derived from the full set of parameters may have the disadvantage of being too insensitive to structural and institutional developments.

In contrast, the two sacrifice ratios derived from actual developments, $\left(\mathrm{SR}_{u}\right)$ and $\left(\mathrm{SR}_{q}\right)$, are less sensitive to whether costs of disinflation are measured by changes in the output gap or by changes in unemployment. The correlation between $\left(\mathrm{SR}_{u}\right)$ and $\left(\mathrm{SR}_{q}\right)$ is relatively high, both within each period 
and in terms of the implied change over time. As a group, however, $\left(S_{u}\right)$ and $\left(S_{q}\right)$ are only weakly or even negatively correlated with the other measures, likely reflecting the lack of controls for supply shocks and the sensitivity to measurement uncertainties inherent in this methodology. Indeed, as illustrated for the gap-based measures in Annex Table 5, even for broadly similar periods and rates of disinflation, minor changes in the definition and measurement of output losses can have a major impact on the estimated sacrifice ratios.

\section{Summary and conclusion}

Relying on several methods of estimating sacrifice ratios for a sample of 19 countries, this paper looks at whether the widespread disinflation of the past 15 years has been accompanied by changes in labour and product market rigidities that have influenced the sacrifice ratio, the cumulative output and employment losses arising from a permanent reduction of inflation. The principal findings are:

(i) When viewed as a whole, the estimates suggest that sacrifice ratios increased between the 1980s and the 1990s in nearly every country in the sample. Averaging over all countries and methods of estimation, sacrifice ratios have increased from 1.5 to 2.5 while average rates of inflation have fallen from $8 \%$ to $3 \frac{1}{2} \%$;

(ii) Lower rates of inflation have been accompanied by a flattening of aggregate supply curves so that a higher proportion of a change in nominal demand growth is now reflected in real output. This flattening can be attributed to changes in both real and nominal rigidities: prices and wages appear to have become less responsive to excess supply conditions in product and labour markets, while changes in nominal wages and prices appear subject to longer lags;

(iii) Of the three principal methods of estimation used, the sacrifice ratios derived from the slope of the aggregate supply and from actual developments in inflation, output and unemployment during periods of disinflation point to the largest increases in the costs of disinflation. In contrast, sacrifice ratios derived from structural estimates of price and wage equations are rather insensitive to changes in both market conditions and rates of inflation and point to only modest or no increases in the costs of disinflation;

(iv) Estimates of sacrifice ratios for individual countries are highly sensitive to the estimation methods used, which may, in part, explain the lack of consensus often found in the literature. For instance, due to an unusually high degree of nominal inertia, sacrifice ratios derived from the aggregate supply give the United States a very low ranking, whereas measures based on actual developments rank the United States among the countries with relatively low costs of disinflation. Italy, by contrast, does poorly when using actual developments but receives a high rank from both the aggregate supply curve and t;e structural estimates. The main exception to 
this general sensitivity to the choice of method is Germany, which is consistently ranked among the countries with the highest costs of disinflation;

(v) Although most of the measures point to an increase in sacrifice ratios, there are several caveats concerning the size and source of this increase:

- while there are theoretical arguments pointing to higher inflation inertia rather than greater real rigidity as the principal source of larger sacrifice ratios, the empirical evidence is, at best, ambiguous. Our preferred measure derived from the aggregate supply curve does not allow for this distinction and most of the changes in nominal and real rigidities identified in the structural estimates are small and insignificant. Moreover, we found little evidence that initial rates of inflation have had any significant impact on the sacrifice ratios derived from actual developments. On the other hand, when testing the influence of inflation on the slope of the aggregate supply curve more directly, we found strong evidence that lower rates of inflation tend to flatten supply curves, both in crosscountry estimates for all 19 countries and over time in individual countries;

- it should also be recalled that policies aimed at reducing inflation have not been implemented in a vacuum, but have coincided with important structural and institutional developments. Such developments create a risk that our estimates of the effect of inflation are capturing the influence of factors that have not been taken into account. For example, in some countries the stance of fiscal policy may have influenced the credibility of monetary policy measures to reduce inflation. Similarly, it may be that the decline in inflation and the rise in nominal inertia should be viewed in a broader framework of more independent central banks and firmer commitments to price stability. Indeed, in many of those countries that have succeeded in significantly improving their inflation performance, central banks have gained a higher degree of independence and several researchers associate the rise in rigidities with more independent central banks rather than with lower rates of inflation.

Despite these caveats and ambiguities, the empirical evidence does contain some implications for monetary policy. Regardless of the underlying sources, it thus seems fairly evident that aggregate supply curves are flatter when inflation is low. Thus, a tightening of monetary policy now has stronger real output effects than in the past, while the adjustment of prices takes somewhat longer. By the same token, positive nominal demand shocks will take longer to affect inflation, perhaps giving policymakers more time to implement compensatory or offsetting measures.

However, the flattening of aggregate supply curves should not be construed to imply that central banks should relax their commitment to price stability in order to reduce nominal inertia. Indeed, this commitment is only one among several possible sources of nominal inertia and, as agents adjust their 
behaviour to an environment with low and stable inflation, some of the additional inertia present in our estimates may well dissipate.

It should be kept in mind that the output losses arising from tighter monetary policy also depend on structural and institutional factors in product and labour markets and not just on central bank independence and credibility. For instance, the Federal Reserve and the Bundesbank are equally independent and probably also equally credible. Nonetheless, according to sacrifice ratios derived from actual developments the costs of reducing inflation are much lower in the United States than in Germany. One reason for this is likely to be that flexible and competitive markets partly offset the effects of high nominal inertia and thus attenuate the output losses in the United States. In Germany, by contrast, lack of market flexibility and associated real rigidities imply that inflation only declines in response to a significant rise in unemployment and output slack.

Recognising this interaction of monetary policies with imperfections in product and labour markets might be particularly relevant should policymakers wish to offset the effects of a permanent and negative supply shock when the economy is on the "flat" part of the Phillips curve. Tighter policies (i.e. a movement along the new and higher Phillips curve) would, in such circumstances, be associated with high output losses, and there is probably little that monetary policy could do to directly affect expectations of inflation. However, structural measures to strengthen the influence of market forces might (by shifting the Phillips curve down) help to offset the negative supply shocks and thus "ease the pain" of disinflationary policies. 


\section{Tables}

\section{Table 1}

Average inflation rates

Cumulative rates, in percentages

\begin{tabular}{|l|r|r|r|r||c|c|c|c|}
\hline \multirow{2}{*}{ Countries } & \multicolumn{9}{|c||}{$1965-85$} & \multicolumn{4}{c|}{$1985-98$} \\
\cline { 2 - 8 } & $\Delta p c$ & $\Delta p y$ & $\Delta w$ & $\Delta u l c$ & $\Delta p c$ & $\Delta p y$ & $\Delta w$ & $\Delta u l c$ \\
\hline United States & 5.6 & 5.7 & 6.7 & 5.9 & 3.1 & 2.9 & 3.7 & 3.0 \\
Japan & 6.4 & 6.0 & 11.1 & 7.3 & 1.2 & 1.0 & 2.2 & 1.3 \\
Germany & 4.0 & 4.3 & 7.5 & 4.9 & 2.2 & 2.5 & 3.7 & 1.5 \\
France & 8.2 & 8.1 & 11.6 & 8.9 & 2.5 & 2.6 & 3.7 & 2.1 \\
Italy & 11.3 & 11.6 & 15.2 & 11.8 & 5.5 & 5.6 & 6.2 & 4.6 \\
United Kingdom & 9.3 & 9.8 & 12.4 & 9.5 & 4.4 & 4.3 & 6.2 & 4.2 \\
Canada & 6.6 & 6.8 & 8.3 & 7.1 & 2.8 & 2.4 & 3.9 & 2.3 \\
Australia & 8.1 & 8.3 & 10.6 & 8.5 & 4.3 & 4.0 & 4.9 & 3.9 \\
Belgium & 6.1 & 6.0 & 10.6 & 6.7 & 2.6 & 2.9 & 3.8 & 2.2 \\
Denmark & 8.6 & 8.5 & 10.9 & 8.9 & 2.7 & 2.8 & 4.1 & 3.0 \\
Finland & 8.9 & 9.3 & 13.1 & 9.9 & 3.4 & 3.5 & 6.1 & 3.0 \\
Ireland & 11.1 & 10.9 & 15.3 & 11.4 & 2.8 & 2.9 & 5.2 & 1.6 \\
Netherlands & 5.7 & 6.0 & 8.8 & 6.0 & 1.8 & 1.6 & 2.5 & 1.2 \\
New Zealand & 10.1 & 10.1 & 12.6 & 12.4 & 5.5 & 5.3 & 5.8 & 4.7 \\
Norway & 7.4 & 7.5 & 10.0 & 7.4 & 3.9 & 2.7 & 5.4 & 3.4 \\
Portugal & 14.5 & 14.1 & 19.0 & 14.4 & 9.1 & 9.8 & 11.5 & 9.3 \\
Spain & 11.9 & 12.0 & 16.8 & 12.4 & 5.4 & 5.7 & 6.0 & 5.6 \\
Sweden & 8.3 & 8.0 & 10.2 & 8.3 & 4.9 & 4.4 & 6.4 & 4.4 \\
Switzerland & 4.5 & 4.5 & 7.0 & 5.0 & 2.5 & 2.4 & 2.9 & 2.5 \\
\hline Average & 8.2 & 8.3 & 11.5 & 8.8 & 3.7 & 3.6 & 5.0 & 3.3 \\
\hline Notation: $p c=$ consumption deflator; $p y=$ GDP deflator; $w=$ compensation per employee; ulc $=$ unit labour costs \\
(all in logs); and $\Delta=$ first difference operator. (all in logs); and $\Delta=$ first-difference operator. & \\
\hline
\end{tabular}


Table 2

Slope of the aggregate supply curve and sacrifice ratios

Unconstrained estimates

\begin{tabular}{|c|c|c|c|c|c|c|c|c|c|}
\hline \multirow[t]{2}{*}{ Country } & \multicolumn{4}{|c|}{ 1965-85 } & \multicolumn{4}{|c|}{ 1985-98 } & \multirow[t]{2}{*}{$\chi^{2}$ test } \\
\hline & $\beta$ & $\gamma$ & $\lambda$ & SR & $\beta$ & $\gamma$ & $\lambda$ & SR & \\
\hline United States & 0.19 & 0.63 & 0.39 & 4.25 & $0.14 *$ & 0.87 & $0.13 *$ & 6.15 & 0.80 \\
\hline Japan & 0.69 & 0.26 & 0.80 & 0.45 & 0.16 & 0.54 & $0.07 *$ & 5.25 & 0.02 \\
\hline Germany & 0.36 & 0.37 & 0.33 & 1.65 & 0.23 & 0.50 & $0.26^{*}$ & 3.85 & 0.39 \\
\hline France & 0.44 & 0.59 & 0.48 & 1.25 & 0.11 & 0.67 & 0.17 & 8.10 & 0.01 \\
\hline Italy & 0.65 & 0.40 & 0.35 & 0.55 & 0.45 & 0.28 & 0.27 & 1.20 & 0.09 \\
\hline United Kingdom & 0.57 & 0.39 & 0.72 & 0.75 & 0.27 & 0.45 & 0.34 & 2.70 & 0.26 \\
\hline Canada & 0.44 & 0.40 & 0.41 & 1.25 & 0.31 & $0.38 *$ & 0.33 & 2.25 & 0.35 \\
\hline Australia & 0.59 & 0.41 & 0.49 & 0.70 & 0.39 & 0.50 & 0.26 & 1.55 & 0.22 \\
\hline Belgium & 0.56 & 0.21 & 0.57 & 0.80 & $0.27 *$ & 0.46 & 0.31 & 2.70 & 0.18 \\
\hline Denmark & 0.45 & 0.46 & 0.51 & 1.20 & 0.22 & 0.53 & $0.13 *$ & 3.55 & 0.02 \\
\hline Finland & 0.59 & 0.17 & 0.59 & 0.70 & 0.21 & $0.29 *$ & 0.17 & 3.75 & 0.00 \\
\hline Ireland & 0.69 & 0.16 & 0.69 & 0.45 & $0.06^{*}$ & $0.30 *$ & $0.17 *$ & 15.65 & 0.09 \\
\hline Netherlands & 0.39 & 0.49 & 0.24 & 1.55 & 0.39 & 0.35 & 0.11 & 1.55 & 0.99 \\
\hline New Zealand & 0.61 & 0.48 & $0.35^{*}$ & 0.65 & 0.53 & 0.53 & $0.32 *$ & 0.90 & 0.18 \\
\hline Norway & 0.77 & $0.17 *$ & $0.05^{*}$ & 0.30 & 0.76 & $0.10 *$ & $0.11 *$ & 0.30 & 0.99 \\
\hline Portugal & 0.58 & 0.48 & 0.62 & 0.70 & 0.42 & 0.52 & 0.32 & 1.40 & 0.55 \\
\hline Spain & 0.60 & 0.59 & $0.11 *$ & 0.65 & 0.52 & 0.41 & 0.22 & 0.90 & 0.66 \\
\hline Sweden & 0.39 & 0.42 & 0.40 & 1.55 & 0.41 & $0.07 *$ & 0.57 & 1.45 & 0.75 \\
\hline Switzerland & 0.13 & 0.53 & $0.19 *$ & 6.70 & 0.30 & 0.41 & $0.15^{*}$ & 2.35 & 0.35 \\
\hline Average & 0.50 & 0.40 & 0.45 & 1.40 & 0.30 & 0.45 & 0.25 & 3.45 & - \\
\hline \multicolumn{10}{|c|}{$\begin{array}{l}\text { Note: Estimates are based on the following equation: } \\
\pi=\alpha+\beta \Delta y+\lambda q_{-1}+\gamma \pi_{-1}+\phi(p m-\pi)_{-1}+\varepsilon \\
\text { with } \pi=\text { the rate of inflation (GDP deflator), } p m=\text { import prices, } y=\text { nominal GDP, } q=\text { real output gap and } \Delta \text { the first- } \\
\text { difference operator (for variables in logs). SR is defined as }(1-\beta) / \beta \text {. Coefficients marked with } * \text { are not significant. Estimates } \\
\text { of } \alpha \text { and } \phi \text { are not shown. The last column shows the p-value from a } \chi^{2} \text { test for the equality of } \beta \text { over the two periods. }\end{array}$} \\
\hline
\end{tabular}


Table 3

Alternative sacrifice ratios from the unconstrained model

\begin{tabular}{|c|c|c|c|c|}
\hline \multirow[t]{2}{*}{ Country } & \multicolumn{2}{|c|}{ 1965-85 } & \multicolumn{2}{|c|}{ 1985-98 } \\
\hline & $\gamma / \beta$ & $\gamma / \lambda$ & $\gamma / \beta$ & $\gamma / \lambda$ \\
\hline United States & 3.32 & 1.62 & 6.21 & 6.69 \\
\hline Japan & 0.38 & 0.33 & 3.38 & 7.71 \\
\hline Germany & 1.03 & 1.12 & 2.17 & 1.92 \\
\hline France & 1.34 & 1.23 & 6.10 & 3.94 \\
\hline Italy & 0.63 & 1.14 & 0.62 & 1.04 \\
\hline United Kingdom & 0.66 & 0.54 & 1.67 & 1.32 \\
\hline Canada & 0.91 & 0.98 & 1.23 & 1.15 \\
\hline Australia & 0.69 & 0.84 & 1.28 & 1.92 \\
\hline Belgium & 0.38 & 0.37 & 1.70 & 1.48 \\
\hline Denmark & 1.03 & 0.90 & 2.41 & 4.08 \\
\hline Finland & 0.27 & 0.29 & 1.38 & 1.71 \\
\hline Ireland & 0.23 & 0.23 & 5.00 & 1.76 \\
\hline Netherlands & 1.26 & 2.04 & 0.90 & 3.18 \\
\hline New Zealand & 0.79 & 1.37 & 1.00 & 1.66 \\
\hline Norway & 0.22 & 3.40 & 0.13 & 0.91 \\
\hline Portugal & 0.80 & 0.77 & 1.24 & 1.63 \\
\hline Spain & 0.96 & 5.36 & 0.79 & 1.86 \\
\hline Sweden & 1.08 & 1.05 & 0.17 & 0.12 \\
\hline Switzerland & 3.79 & 2.79 & 1.37 & 2.73 \\
\hline Average & 1.05 & 1.40 & 2.05 & 2.45 \\
\hline Correlation with Table 2 & 0.95 & 0.25 & 0.80 & 0.30 \\
\hline Rank correlation & 0.95 & 0.05 & 0.65 & 0.10 \\
\hline
\end{tabular}

Note: Definitions of sacrifice ratios are based on the coefficient estimates shown in Table 2. Correlation with Table 2 is the cross-country correlation coefficient of sacrifice ratios between the column indicated and the comparable column in Table 2. Rank correlation is the Spearman's rho across countries for the sacrifice ratios shown in each sample period. 
Table 4

Sacrifice ratios: constrained estimates

\begin{tabular}{|c|c|c|c|c|c|c|c|c|c|c|}
\hline \multirow[t]{2}{*}{ Countries } & \multicolumn{5}{|c|}{$1965-85$} & \multicolumn{5}{|c|}{ 1985-98 } \\
\hline & $\beta$ & $\gamma$ & $\lambda$ & $\phi$ & SR & $\beta$ & $\gamma$ & $\lambda$ & $\phi$ & SR \\
\hline United States & $\begin{array}{l}0.27 \\
0.33\end{array}$ & $\begin{array}{l}- \\
-\end{array}$ & $\begin{array}{c}0.42 \\
-\end{array}$ & $\begin{array}{l}0.04 \\
0.05\end{array}$ & $\begin{array}{l}2.70 \\
2.05\end{array}$ & $\begin{array}{l}0.13 \\
0.13\end{array}$ & $\begin{array}{l}- \\
-\end{array}$ & $\begin{array}{c}0.13 \\
-\end{array}$ & $\begin{array}{l}0.12 \\
0.12\end{array}$ & $\begin{array}{l}6.70 \\
6.70\end{array}$ \\
\hline Japan & $\begin{array}{l}0.71 \\
0.72\end{array}$ & $\begin{array}{l}- \\
-\end{array}$ & $\begin{array}{c}0.78 \\
-\end{array}$ & $\begin{array}{l}- \\
-\end{array}$ & $\begin{array}{l}0.40 \\
0.40\end{array}$ & $\begin{array}{l}0.16 \\
0.16\end{array}$ & $\begin{array}{l}0.53 \\
0.46\end{array}$ & $\begin{array}{c}0.07 * \\
-\end{array}$ & $\begin{array}{l}0.04 \\
0.04\end{array}$ & $\begin{array}{l}3.30 \\
2.90\end{array}$ \\
\hline Germany & $\begin{array}{l}0.46 \\
0.34\end{array}$ & $\begin{array}{c}- \\
0.37 \\
\end{array}$ & 0.24 & $\begin{array}{l}0.11 \\
0.07\end{array}$ & $\begin{array}{l}1.15 \\
1.10\end{array}$ & $\begin{array}{l}0.30 \\
0.23\end{array}$ & - & $\begin{array}{c}0.14 \\
-\end{array}$ & $\begin{array}{l}0.06 \\
0.09\end{array}$ & $\begin{array}{l}2.35 \\
3.35 \\
\end{array}$ \\
\hline France & $\begin{array}{l}0.42 \\
0.44\end{array}$ & - & $\begin{array}{c}0.48 \\
-\end{array}$ & $\begin{array}{l}0.05 \\
0.05\end{array}$ & $\begin{array}{l}1.35 \\
1.25\end{array}$ & $\begin{array}{l}0.11^{*} \\
0.14\end{array}$ & $\begin{array}{l}0.67 \\
0.65 \\
\end{array}$ & $\begin{array}{c}0.17 \\
- \\
\end{array}$ & $\begin{array}{l}0.04 * \\
0.03 *\end{array}$ & $\begin{array}{l}6.10 \\
4.65\end{array}$ \\
\hline Italy & $\begin{array}{l}0.63 \\
0.60 \\
\end{array}$ & - & $\begin{array}{c}0.36 \\
- \\
\end{array}$ & $\begin{array}{l}0.06 \\
0.03 *\end{array}$ & $\begin{array}{l}0.60 \\
0.65\end{array}$ & $\begin{array}{l}0.45 \\
0.38 \\
\end{array}$ & $\begin{array}{l}0.28 \\
0.33\end{array}$ & $\begin{array}{c}0.27 \\
-\end{array}$ & $\begin{array}{l}0.03^{*} \\
0.04\end{array}$ & $\begin{array}{l}0.60 \\
0.85\end{array}$ \\
\hline United Kingdom & $\begin{array}{l}0.61 \\
0.63 \\
\end{array}$ & $\begin{array}{l}- \\
-\end{array}$ & $\begin{array}{c}0.69 \\
- \\
\end{array}$ & $\begin{array}{l}0.17 \\
0.16 \\
\end{array}$ & $\begin{array}{l}0.65 \\
0.60 \\
\end{array}$ & $\begin{array}{l}0.38 \\
0.31\end{array}$ & - & $\begin{array}{c}0.22 \\
- \\
\end{array}$ & $\begin{array}{l}0.02 * \\
0.06^{*}\end{array}$ & $\begin{array}{l}1.60 \\
2.25\end{array}$ \\
\hline Canada & $\begin{array}{l}0.51 \\
0.45\end{array}$ & $\begin{array}{l}- \\
-\end{array}$ & $\begin{array}{c}0.31 \\
-\end{array}$ & - & $\begin{array}{l}1.00 \\
1.20\end{array}$ & $\begin{array}{l}0.27 \\
0.25\end{array}$ & - & $\begin{array}{c}0.23 \\
- \\
\end{array}$ & $\begin{array}{l}0.14 \\
0.15\end{array}$ & $\begin{array}{l}2.75 \\
2.90 \\
\end{array}$ \\
\hline Australia & $\begin{array}{l}0.59 \\
0.57 \\
\end{array}$ & $\begin{array}{l}- \\
- \\
\end{array}$ & $\begin{array}{c}0.49 \\
- \\
\end{array}$ & $\begin{array}{l}- \\
-\end{array}$ & $\begin{array}{l}0.70 \\
0.75 \\
\end{array}$ & $\begin{array}{l}0.40 \\
0.36\end{array}$ & $\begin{array}{l}- \\
-\end{array}$ & $\begin{array}{c}0.18 \\
-\end{array}$ & $\begin{array}{l}0.06 \\
0.07\end{array}$ & $\begin{array}{l}1.50 \\
1.80 \\
\end{array}$ \\
\hline Belgium & $\begin{array}{l}0.62 \\
0.62 \\
\end{array}$ & - & $\begin{array}{c}0.62 \\
- \\
\end{array}$ & $\begin{array}{l}0.13 \\
0.13 \\
\end{array}$ & $\begin{array}{l}0.60 \\
0.60 \\
\end{array}$ & $\begin{array}{l}0.38 \\
0.32 \\
\end{array}$ & - & $\begin{array}{c}0.25 \\
- \\
\end{array}$ & $\begin{array}{l}0.04^{*} \\
0.05^{*}\end{array}$ & $\begin{array}{l}1.90 \\
2.15\end{array}$ \\
\hline Denmark & $\begin{array}{l}0.48 \\
0.50 \\
\end{array}$ & $\begin{array}{l}- \\
- \\
\end{array}$ & $\begin{array}{c}0.52 \\
- \\
\end{array}$ & $\begin{array}{l}0.17 \\
0.17 \\
\end{array}$ & $\begin{array}{l}1.10 \\
1.00 \\
\end{array}$ & $\begin{array}{l}0.30 \\
0.16 \\
\end{array}$ & $\begin{array}{l}- \\
- \\
\end{array}$ & $\begin{array}{c}0.05^{*} \\
- \\
\end{array}$ & $\begin{array}{l}- \\
- \\
\end{array}$ & $\begin{array}{l}2.35 \\
5.25 \\
\end{array}$ \\
\hline Finland & $\begin{array}{l}0.68 \\
0.59 \\
\end{array}$ & $\begin{array}{c}- \\
0.17 \\
\end{array}$ & $\begin{array}{c}0.33 \\
- \\
\end{array}$ & - & $\begin{array}{l}0.45 \\
0.30 \\
\end{array}$ & $\begin{array}{l}0.22 \\
0.20 \\
\end{array}$ & $\begin{array}{l}0.29 \\
0.26 \\
\end{array}$ & $\begin{array}{c}0.17 \\
- \\
\end{array}$ & $\begin{array}{l}0.03 * \\
0.04 *\end{array}$ & $\begin{array}{l}1.30 \\
1.30 \\
\end{array}$ \\
\hline Ireland & $\begin{array}{l}0.80 \\
0.72 \\
\end{array}$ & $\begin{array}{l}- \\
- \\
\end{array}$ & $\begin{array}{c}0.60 * \\
- \\
\end{array}$ & $\begin{array}{l}0.04 * \\
0.06 *\end{array}$ & $\begin{array}{l}0.25 \\
0.40 \\
\end{array}$ & $\begin{array}{l}0.33^{*} \\
0.33\end{array}$ & - & $\begin{array}{c}0.35^{*} \\
- \\
\end{array}$ & $\begin{array}{l}0.02 * \\
0.02 *\end{array}$ & $\begin{array}{l}2.05 \\
2.05\end{array}$ \\
\hline Netherlands & $\begin{array}{l}0.37 \\
0.32 \\
\end{array}$ & $\begin{array}{l}- \\
- \\
\end{array}$ & $\begin{array}{c}0.22 \\
- \\
\end{array}$ & $\begin{array}{l}0.11 \\
0.11 \\
\end{array}$ & $\begin{array}{l}1.70 \\
2.10 \\
\end{array}$ & $\begin{array}{l}0.44 \\
0.39 \\
\end{array}$ & $\begin{array}{l}- \\
- \\
\end{array}$ & $\begin{array}{c}0.08^{*} \\
- \\
\end{array}$ & $\begin{array}{l}- \\
- \\
\end{array}$ & $\begin{array}{l}1.25 \\
1.55 \\
\end{array}$ \\
\hline New Zealand & $\begin{array}{l}0.57 \\
0.54\end{array}$ & $\begin{array}{l}- \\
-\end{array}$ & $\begin{array}{c}0.36^{*} \\
- \\
\end{array}$ & - & $\begin{array}{l}0.75 \\
0.85\end{array}$ & $\begin{array}{l}0.52 \\
0.47\end{array}$ & - & $\begin{array}{c}0.36 \\
- \\
\end{array}$ & $\begin{array}{l}0.17 \\
0.21\end{array}$ & $\begin{array}{l}0.90 \\
1.15 \\
\end{array}$ \\
\hline Norway & $\begin{array}{c}0.80 \\
(0.52) \\
\end{array}$ & $\begin{array}{l}- \\
- \\
\end{array}$ & $\begin{array}{c}0.03 * \\
- \\
\end{array}$ & $\begin{array}{c}0.03 * \\
- \\
\end{array}$ & $\begin{array}{c}0.25 \\
(0.90) \\
\end{array}$ & $\begin{array}{c}0.82 \\
(0.58) \\
\end{array}$ & - & $\begin{array}{c}0.10^{*} \\
- \\
\end{array}$ & $\begin{array}{c}0.10^{*} \\
(0.07 *)\end{array}$ & $\begin{array}{c}0.20 \\
(0.70) \\
\end{array}$ \\
\hline Portugal & $\begin{array}{l}0.53 \\
0.55 \\
\end{array}$ & $\begin{array}{l}- \\
- \\
\end{array}$ & $\begin{array}{c}0.63 \\
- \\
\end{array}$ & $\begin{array}{l}- \\
- \\
\end{array}$ & $\begin{array}{l}0.90 \\
0.80 \\
\end{array}$ & $\begin{array}{l}0.43 \\
0.41 \\
\end{array}$ & $\begin{array}{l}- \\
- \\
\end{array}$ & $\begin{array}{c}0.38 \\
- \\
\end{array}$ & $\begin{array}{l}0.17 \\
0.18\end{array}$ & $\begin{array}{l}1.30 \\
1.45 \\
\end{array}$ \\
\hline Spain & $\begin{array}{l}0.60 \\
0.41 \\
\end{array}$ & $\begin{array}{c}0.59 \\
- \\
\end{array}$ & $\begin{array}{c}0.11 * \\
- \\
\end{array}$ & $\begin{array}{l}0.08 \\
0.06 \\
\end{array}$ & $\begin{array}{l}1.00 \\
1.45 \\
\end{array}$ & $\begin{array}{l}0.54 \\
0.40 \\
\end{array}$ & $\begin{array}{l}- \\
- \\
\end{array}$ & $\begin{array}{c}0.23 \\
- \\
\end{array}$ & $\begin{array}{l}0.12 \\
0.15 \\
\end{array}$ & $\begin{array}{l}0.85 \\
1.50 \\
\end{array}$ \\
\hline Sweden & $\begin{array}{l}0.52 \\
0.39 \\
\end{array}$ & $\begin{array}{c}- \\
0.42 \\
\end{array}$ & $\begin{array}{c}0.30 \\
- \\
\end{array}$ & $\begin{array}{l}0.07 \\
0.09 \\
\end{array}$ & $\begin{array}{l}0.75 \\
1.10 \\
\end{array}$ & $\begin{array}{l}0.41 \\
0.46 \\
\end{array}$ & $\begin{array}{l}0.06^{*} \\
0.11^{*} \\
\end{array}$ & $\begin{array}{c}0.57 \\
- \\
\end{array}$ & $\begin{array}{l}0.08^{*} \\
0.05^{*}\end{array}$ & $\begin{array}{l}0.15 \\
0.25 \\
\end{array}$ \\
\hline Switzerland & $\begin{array}{l}0.14 \\
0.15\end{array}$ & $\begin{array}{l}0.53 \\
0.55\end{array}$ & $\begin{array}{c}0.19 * \\
- \\
\end{array}$ & $\begin{array}{l}0.12 \\
0.13\end{array}$ & $\begin{array}{l}3.80 \\
3.65 \\
\end{array}$ & $\begin{array}{l}0.36 \\
0.20 \\
\end{array}$ & - & $\begin{array}{c}0.03 * \\
- \\
\end{array}$ & $\begin{array}{l}- \\
-\end{array}$ & $\begin{array}{l}1.80 \\
4.00 \\
\end{array}$ \\
\hline $\begin{array}{l}\text { Average } \\
\text { (unweighted) }\end{array}$ & $\begin{array}{l}0.55 \\
0.50 \\
\end{array}$ & $\begin{array}{l}0.45 \\
0.45 \\
\end{array}$ & $\begin{array}{l}0.40 \\
0.50 \\
\end{array}$ & $\begin{array}{l}0.05 \\
0.05 \\
\end{array}$ & $\begin{array}{l}1.05 \\
1.10 \\
\end{array}$ & $\begin{array}{l}0.35 \\
0.30 \\
\end{array}$ & $\begin{array}{l}0.50 \\
0.60 \\
\end{array}$ & $\begin{array}{l}0.20 \\
0.30 \\
\end{array}$ & $\begin{array}{l}0.05 \\
0.05 \\
\end{array}$ & $\begin{array}{l}2.05 \\
2.45 \\
\end{array}$ \\
\hline \multicolumn{11}{|c|}{ 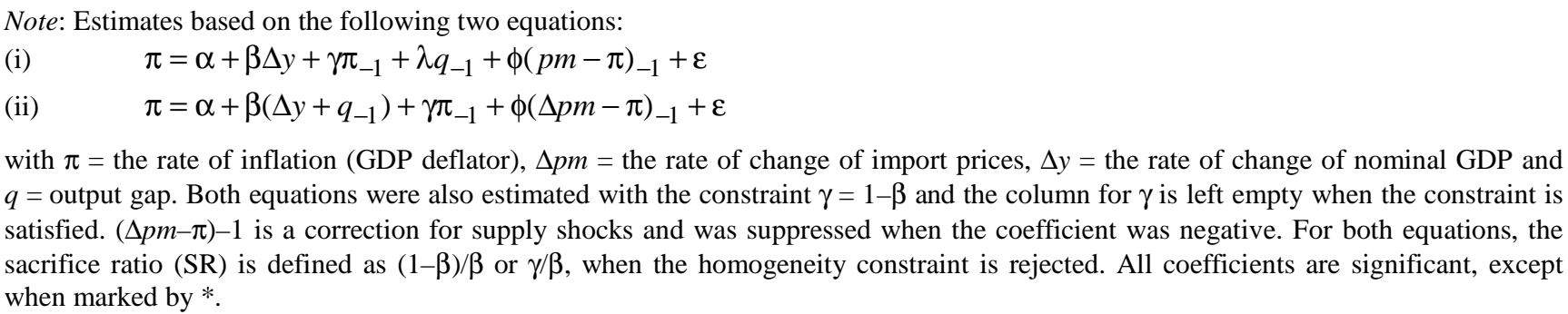 } \\
\hline
\end{tabular}


Table 5

Wage equations

\begin{tabular}{|c|c|c|c|c|c|c|c|c|}
\hline Countries & $\theta$ & $\alpha$ & $\delta$ & $\phi$ & $\Sigma(\eta+\gamma)$ & $\mathrm{R}^{2}$ & $\mathrm{DW}(\mathrm{h})$ & SR \\
\hline United States & $\begin{array}{l}6.88 \\
6.58 \\
\end{array}$ & $\begin{array}{l}-3.68 \\
-3.52 \\
\end{array}$ & - & $\begin{array}{l}0.26 \\
0.27 \\
\end{array}$ & $\begin{array}{l}0.79 \\
0.77 \\
\end{array}$ & $\begin{array}{l}0.81 \\
0.80 \\
\end{array}$ & $\begin{array}{l}1.37 \\
1.42 \\
\end{array}$ & $\begin{array}{l}1.20 \\
1.24 \\
\end{array}$ \\
\hline Japan & $\begin{array}{l}6.06 \\
9.22 \\
\end{array}$ & $\begin{array}{l}-5.43 \\
-8.54 \\
\end{array}$ & $\begin{array}{l}- \\
- \\
\end{array}$ & $\begin{array}{l}0.65 \\
0.64 \\
\end{array}$ & $\begin{array}{l}0.14 \\
0.12 \\
\end{array}$ & $\begin{array}{l}0.95 \\
0.95 \\
\end{array}$ & $\begin{array}{r}(0.15) \\
(-0.29) \\
\end{array}$ & $\begin{array}{l}0.19 \\
0.13 \\
\end{array}$ \\
\hline Germany & $\begin{array}{l}4.86 \\
4.09 \\
\end{array}$ & $\begin{array}{l}-1.70 \\
-1.39 \\
\end{array}$ & $\begin{array}{l}-2.87 \\
-3.20 \\
\end{array}$ & $\begin{array}{l}0.62 \\
0.56 \\
\end{array}$ & $\begin{array}{l}0.21 \\
0.32 \\
\end{array}$ & $\begin{array}{l}0.78 \\
0.71 \\
\end{array}$ & $\begin{array}{l}(0.67) \\
(0.65)\end{array}$ & $\begin{array}{l}2.10 \\
2.98 \\
\end{array}$ \\
\hline France & $\begin{array}{l}6.60 \\
6.58 \\
\end{array}$ & $\begin{array}{l}-2.37 \\
-2.53 \\
\end{array}$ & - & $\begin{array}{l}0.80 \\
0.81 \\
\end{array}$ & $\begin{array}{l}0.20 \\
0.22 \\
\end{array}$ & $\begin{array}{l}0.96 \\
0.93 \\
\end{array}$ & $\begin{array}{l}1.45 \\
1.48 \\
\end{array}$ & $\begin{array}{l}0.97 \\
0.86 \\
\end{array}$ \\
\hline Italy & $\begin{array}{l}16.7 \\
16.0 \\
\end{array}$ & $\begin{array}{l}-6.45 \\
-5.87 \\
\end{array}$ & $\begin{array}{l}-10.8 \\
-10.4 \\
\end{array}$ & $\begin{array}{l}0.73 \\
0.74 \\
\end{array}$ & $\begin{array}{l}0.14 \\
0.10 \\
\end{array}$ & $\begin{array}{l}0.92 \\
0.88 \\
\end{array}$ & $\begin{array}{l}2.26 \\
2.36 \\
\end{array}$ & $\begin{array}{l}0.46 \\
0.48 \\
\end{array}$ \\
\hline United Kingdom & $\begin{array}{l}5.37 \\
5.61 \\
\end{array}$ & $\begin{array}{l}-1.24 \\
-0.45 \\
\end{array}$ & $\begin{array}{l}- \\
- \\
\end{array}$ & $\begin{array}{l}1.12 \\
1.10 \\
\end{array}$ & $\begin{array}{l}-0.17 \\
-0.25\end{array}$ & $\begin{array}{l}0.86 \\
0.86 \\
\end{array}$ & $\begin{array}{l}2.28 \\
3.04 \\
\end{array}$ & $\begin{array}{l}1.85 \\
5.10 \\
\end{array}$ \\
\hline Canada & $\begin{array}{l}7.86 \\
8.13 \\
\end{array}$ & $\begin{array}{l}-3.10 \\
-3.43 \\
\end{array}$ & - & $\begin{array}{l}0.81 \\
0.84 \\
\end{array}$ & $\begin{array}{l}0.13 \\
0.15 \\
\end{array}$ & $\begin{array}{l}0.75 \\
0.62 \\
\end{array}$ & $\begin{array}{l}(0.41) \\
(0.30) \\
\end{array}$ & $\begin{array}{l}0.61 \\
0.47 \\
\end{array}$ \\
\hline Australia & $\begin{array}{l}3.96 \\
3.43 \\
\end{array}$ & $\begin{array}{l}-1.18 \\
-2.68 \\
\end{array}$ & $\begin{array}{l}4.44 \\
2.47 \\
\end{array}$ & $\begin{array}{l}1.68 \\
1.77 \\
\end{array}$ & $\begin{array}{r}-0.75 \\
-0.51 \\
\end{array}$ & $\begin{array}{l}0.81 \\
0.80 \\
\end{array}$ & $\begin{array}{l}2.26 \\
2.59 \\
\end{array}$ & $\begin{array}{l}2.10 \\
0.90 \\
\end{array}$ \\
\hline Belgium & $\begin{array}{l}13.0 \\
12.7 \\
\end{array}$ & $\begin{array}{l}-4.99 \\
-4.96 \\
\end{array}$ & $\begin{array}{l}- \\
- \\
\end{array}$ & $\begin{array}{l}0.53 \\
0.55 \\
\end{array}$ & $\begin{array}{l}0.43 \\
0.44 \\
\end{array}$ & $\begin{array}{l}0.90 \\
0.87 \\
\end{array}$ & $\begin{array}{l}2.06 \\
2.50 \\
\end{array}$ & $\begin{array}{l}1.12 \\
1.08 \\
\end{array}$ \\
\hline Denmark & $\begin{array}{l}4.43 \\
3.95 \\
\end{array}$ & $\begin{array}{l}-1.47 \\
-1.57 \\
\end{array}$ & - & $\begin{array}{l}0.53 \\
0.58 \\
\end{array}$ & $\begin{array}{l}0.33 \\
0.35 \\
\end{array}$ & $\begin{array}{l}0.88 \\
0.81 \\
\end{array}$ & $\begin{array}{l}(-0.15) \\
(-0.42)\end{array}$ & $\begin{array}{l}3.13 \\
2.62 \\
\end{array}$ \\
\hline Finland & $\begin{array}{l}5.51 \\
5.74 \\
\end{array}$ & $\begin{array}{l}-1.78 \\
-2.60 \\
\end{array}$ & $\begin{array}{l}-3.68 \\
-3.97 \\
\end{array}$ & $\begin{array}{l}0.92 \\
0.97 \\
\end{array}$ & $\begin{array}{l}0.05 \\
0.06 \\
\end{array}$ & $\begin{array}{l}0.82 \\
0.79 \\
\end{array}$ & $\begin{array}{l}(-0.42) \\
(-0.26)\end{array}$ & $\begin{array}{l}0.58 \\
0.15 \\
\end{array}$ \\
\hline Ireland & $\begin{array}{l}9.11 \\
9.57 \\
\end{array}$ & $\begin{array}{l}-2.52 \\
-2.53 \\
\end{array}$ & $\begin{array}{l}- \\
-\end{array}$ & $\begin{array}{l}0.80 \\
0.85 \\
\end{array}$ & $\begin{array}{l}0.13 \\
0.06 \\
\end{array}$ & $\begin{array}{l}0.84 \\
0.80 \\
\end{array}$ & $\begin{array}{l}(0.49) \\
(2.19) \\
\end{array}$ & $\begin{array}{l}1.05 \\
0.77\end{array}$ \\
\hline Netherlands & $\begin{array}{l}4.85 \\
5.26 \\
\end{array}$ & $\begin{array}{l}-2.35 \\
-2.47 \\
\end{array}$ & $\begin{array}{l}- \\
- \\
\end{array}$ & $\begin{array}{l}0.45 \\
0.39 \\
\end{array}$ & $\begin{array}{l}0.47 \\
0.48 \\
\end{array}$ & $\begin{array}{l}0.93 \\
0.91 \\
\end{array}$ & $\begin{array}{l}(1.01) \\
(0.93) \\
\end{array}$ & $\begin{array}{l}1.40 \\
1.48 \\
\end{array}$ \\
\hline New Zealand & $\begin{array}{l}2.94 \\
3.14 \\
\end{array}$ & $\begin{array}{l}-1.08 \\
-1.07 \\
\end{array}$ & $\begin{array}{l}- \\
- \\
\end{array}$ & $\begin{array}{l}0.43 \\
0.43 \\
\end{array}$ & $\begin{array}{l}0.36 \\
0.35 \\
\end{array}$ & $\begin{array}{l}0.67 \\
0.27 \\
\end{array}$ & $\begin{array}{l}(1.80) \\
(0.07) \\
\end{array}$ & $\begin{array}{l}4.33 \\
4.37 \\
\end{array}$ \\
\hline Norway & $\begin{array}{l}7.06 \\
6.86 \\
\end{array}$ & $\begin{array}{l}-3.13 \\
-3.57 \\
\end{array}$ & $\begin{array}{l}- \\
- \\
\end{array}$ & $\begin{array}{l}0.49 \\
0.53 \\
\end{array}$ & $\begin{array}{l}0.12 \\
0.14 \\
\end{array}$ & $\begin{array}{l}0.69 \\
0.45 \\
\end{array}$ & $\begin{array}{l}2.03 \\
2.12 \\
\end{array}$ & $\begin{array}{l}0.81 \\
0.66 \\
\end{array}$ \\
\hline Portugal & $\begin{array}{l}11.2 \\
11.1 \\
\end{array}$ & $\begin{array}{l}-6.10 \\
-6.30 \\
\end{array}$ & $\begin{array}{l}- \\
- \\
\end{array}$ & $\begin{array}{l}0.48 \\
0.47 \\
\end{array}$ & $\begin{array}{l}0.53 \\
0.57 \\
\end{array}$ & $\begin{array}{l}0.76 \\
0.69 \\
\end{array}$ & $\begin{array}{l}(2.16) \\
(1.98) \\
\end{array}$ & $\begin{array}{l}0.50 \\
0.50 \\
\end{array}$ \\
\hline Spain & $\begin{array}{l}9.01 \\
9.64\end{array}$ & $\begin{array}{l}-2.87 \\
-3.26 \\
\end{array}$ & $\begin{array}{l}- \\
- \\
\end{array}$ & $\begin{array}{l}0.72 \\
0.82 \\
\end{array}$ & $\begin{array}{l}0.24 \\
0.16 \\
\end{array}$ & $\begin{array}{l}0.90 \\
0.88 \\
\end{array}$ & $\begin{array}{r}(0.07) \\
(-1.21) \\
\end{array}$ & $\begin{array}{l}2.00 \\
1.13 \\
\end{array}$ \\
\hline Sweden & $\begin{array}{l}5.80 \\
6.84 \\
\end{array}$ & $\begin{array}{l}-1.83 \\
-4.75 \\
\end{array}$ & $\begin{array}{l}-3.88 \\
-2.91 \\
\end{array}$ & $\begin{array}{l}0.52 \\
0.67 \\
\end{array}$ & $\begin{array}{l}0.15 \\
0.13 \\
\end{array}$ & $\begin{array}{l}0.64 \\
0.51 \\
\end{array}$ & $\begin{array}{l}1.88 \\
1.79 \\
\end{array}$ & $\begin{array}{l}1.78 \\
0.47 \\
\end{array}$ \\
\hline Switzerland & $\begin{array}{l}1.51 \\
1.53 \\
\end{array}$ & $\begin{array}{l}-0.76 \\
-0.83 \\
\end{array}$ & $\begin{array}{l}- \\
- \\
\end{array}$ & $\begin{array}{l}0.50 \\
0.41 \\
\end{array}$ & $\begin{array}{l}0.15 \\
0.17 \\
\end{array}$ & $\begin{array}{l}0.87 \\
0.83 \\
\end{array}$ & $\begin{array}{r}(-0.01) \\
(0.15)\end{array}$ & $\begin{array}{l}2.50 \\
2.70\end{array}$ \\
\hline \multicolumn{9}{|c|}{$\begin{array}{l}\text { Note: Coefficients obtained from wage equation specified as: } \\
\Delta w_{t}=\theta+\alpha u_{t}+\delta \Delta u_{t}+\phi \Delta p c_{t}+\gamma \Delta p c_{t-i}+\eta \Delta w_{t-i}+\varepsilon_{t} \\
\text { with } w=\text { compensation per employee, } U=\text { rate of unemployment, } p c=\text { consumption deflator, } \varepsilon=\text { an error term and } \Delta=\text { first- } \\
\text { difference operator. } i=1,2 \text { and small letters denote variables in logs. For each country, the first equation shows the parameters } \\
\text { obtained for the full sample period (in most cases } 1965-98 \text { ) while the second equation shows parameters from a sample period } \\
\text { terminating in 1990. Sacrifice ratios (SR) have been calculated as }(1-\phi) \mathrm{U}_{91-98} /(-\alpha) \text {, with } \mathrm{U}_{91-98} \text { denoting the average rate of } \\
\text { unemployment for 1991-98 (for the United Kingdom and Australia; average }(1-\phi) \text { for the other } 17 \text { countries was used). }\end{array}$} \\
\hline
\end{tabular}


Table 7

Structural stability test for wage and price equations ${ }^{1}$

\begin{tabular}{|c|c|c|c|c|}
\hline \multirow[t]{2}{*}{ Countries } & \multirow{2}{*}{$\begin{array}{c}\text { Test for } \\
\text { break in } 1991^{2}\end{array}$} & \multicolumn{3}{|c|}{ Out-of-sample forecast errors: $1991-98$} \\
\hline & & Cumulative & Bias proportion $^{3}$ & RMSE \\
\hline \multirow[t]{2}{*}{ United States } & 0.03 & -2.9 & 0.19 & 0.92 \\
\hline & 0.36 & 1.6 & 0.18 & 0.47 \\
\hline \multirow[t]{2}{*}{ Japan } & 0.04 & -0.1 & 0.00 & 2.44 \\
\hline & 0.96 & 2.9 & 0.14 & 0.96 \\
\hline \multirow[t]{2}{*}{ Germany } & 0.10 & 3.0 & 0.04 & 1.94 \\
\hline & 0.82 & -1.5 & 0.22 & 0.40 \\
\hline \multirow[t]{2}{*}{ France } & 0.84 & 7.0 & 0.48 & 0.77 \\
\hline & 0.47 & -2.8 & 0.38 & 0.56 \\
\hline \multirow[t]{2}{*}{ Italy } & 0.79 & -8.3 & 0.49 & 1.48 \\
\hline & 0.78 & 7.8 & 0.69 & 1.18 \\
\hline \multirow{2}{*}{$\begin{array}{l}\text { United } \\
\text { Kingdom }\end{array}$} & 0.08 & -17.6 & 0.68 & 2.65 \\
\hline & 0.99 & 6.8 & 0.63 & 1.07 \\
\hline \multirow[t]{2}{*}{ Canada } & 0.91 & 5.8 & 0.31 & 1.29 \\
\hline & 0.06 & -10.3 & 0.69 & 1.55 \\
\hline \multirow[t]{2}{*}{ Australia } & 0.29 & 31.8 & 0.90 & 4.20 \\
\hline & 0.66 & -11.9 & 0.88 & 1.60 \\
\hline \multirow[t]{2}{*}{ Belgium } & 0.51 & 3.4 & 0.11 & 1.30 \\
\hline & 0.21 & -3.0 & 0.14 & 0.98 \\
\hline \multirow[t]{2}{*}{ Denmark } & 0.94 & 10.2 & 0.87 & 1.37 \\
\hline & 0.29 & -9.0 & 0.64 & 1.40 \\
\hline \multirow{2}{*}{ Finland } & 0.11 & 24.9 & 0.57 & 4.11 \\
\hline & 0.78 & -2.9 & 0.28 & 0.68 \\
\hline \multirow[t]{2}{*}{ Ireland } & 0.46 & -3.8 & 0.04 & 2.36 \\
\hline & 0.60 & -0.3 & 0.00 & 1.82 \\
\hline \multirow[t]{2}{*}{ Netherlands } & 0.99 & -2.7 & 0.31 & 0.61 \\
\hline & 0.46 & 2.3 & 0.28 & 0.55 \\
\hline \multirow[t]{2}{*}{ New Zealand } & 0.99 & -3.2 & 0.25 & 0.82 \\
\hline & 0.58 & -16.5 & 0.68 & 2.50 \\
\hline \multirow[t]{2}{*}{ Norway } & 0.98 & 9.4 & 0.76 & 1.35 \\
\hline & 0.85 & -5.7 & 0.33 & 1.22 \\
\hline \multirow[t]{2}{*}{ Portugal } & 0.90 & -1.8 & 0.01 & 2.81 \\
\hline & 0.99 & 1.6 & 0.02 & 1.56 \\
\hline \multirow[t]{2}{*}{ Spain } & 0.27 & 10.9 & 0.29 & 2.53 \\
\hline & 0.96 & -6.6 & 0.34 & 1.41 \\
\hline \multirow[t]{2}{*}{ Sweden } & 0.25 & 36.5 & 0.72 & 5.39 \\
\hline & 0.05 & -10.4 & 0.41 & 2.00 \\
\hline \multirow[t]{2}{*}{ Switzerland } & 0.59 & 5.0 & 0.29 & 1.17 \\
\hline & $0.03^{4}$ & 7.8 & 0.75 & 1.13 \\
\hline \multicolumn{5}{|c|}{$\begin{array}{l}{ }^{1} \text { Results for wage equations are shown in the top line of each row, and those for price equations at } \\
\text { shown in the bottom line. }{ }^{2} \text { The numbers refer to p-values from a chi-square log-likelihood test fo } \\
\text { structural stability. }{ }^{3} \text { This column shows the proportion of the forecast error that is accounted for b } \\
\text { the difference between the mean forecast value and the mean of the actual series from 1991-98 } \\
\text { b Break in 1990. }\end{array}$} \\
\hline
\end{tabular}


Table 8

Sacrifice ratios: reduced-form estimates

\begin{tabular}{|c|c|c|c|c|c|c|c|c|c|c|c|c|}
\hline \multirow[t]{2}{*}{ Countries } & \multirow[t]{2}{*}{$U_{1991-98}$} & \multirow[t]{2}{*}{$\lambda$} & \multicolumn{5}{|c|}{ Short period (1965-90) } & \multicolumn{5}{|c|}{ Full period (1965-98) } \\
\hline & & & $\alpha(\Delta w)$ & $\phi(\Delta w)$ & $\beta(\Delta p c)$ & $\delta(\Delta p c)$ & SR & $\alpha(\Delta w)$ & $\phi(\Delta w)$ & $\beta(\Delta p c)$ & $\delta(\Delta p c)$ & SR \\
\hline United States & 6.0 & 0.449 & 3.52 & 0.27 & 0.31 & 0.19 & 1.23 & 3.68 & 0.26 & 0.26 & 0.22 & 1.23 \\
\hline Japan & 3.0 & 0.084 & 8.54 & 0.64 & -0.02 & 0.43 & 0.27 & 5.43 & 0.65 & 0.18 & 0.41 & 0.23 \\
\hline Germany & 9.4 & 0.276 & 1.39 & 0.56 & 0.30 & 0.11 & 1.24 & 1.70 & 0.62 & 0.25 & 0.13 & 1.24 \\
\hline France & 11.5 & 0.582 & 2.53 & 0.81 & 0.24 & 0.21 & 1.50 & 2.37 & 0.80 & 0.22 & 0.22 & 1.62 \\
\hline Italy & 10.9 & 0.150 & 5.87 & 0.74 & 0.32 & 0.15 & 0.42 & 6.45 & 0.73 & 0.31 & 0.12 & 0.43 \\
\hline United Kingdom & 8.5 & 0.561 & 0.45 & 0.62 & 0.16 & 0.48 & 3.06 & 1.24 & 0.60 & 0.11 & 0.45 & 2.77 \\
\hline Canada & 10.0 & 0.542 & 3.43 & 0.84 & 0.17 & 0.21 & 1.36 & 3.10 & 0.81 & 0.23 & 0.27 & 1.20 \\
\hline Australia & 9.3 & 0.435 & 2.68 & 0.62 & 0.13 & 0.28 & 1.75 & 1.18 & 0.60 & 0.19 & 0.27 & 2.15 \\
\hline Belgium & 11.9 & 0.297 & 4.96 & 0.55 & 0.20 & 0.15 & 1.17 & 4.99 & 0.53 & 0.17 & 0.23 & 1.22 \\
\hline Denmark & 9.8 & 0.394 & 1.57 & 0.58 & 0.23 & 0.18 & 1.80 & 1.47 & 0.53 & 0.22 & 0.19 & 2.02 \\
\hline Finland & 12.9 & 0.524 & 2.60 & 0.97 & 0.12 & 0.12 & 2.09 & 1.78 & 0.92 & 0.18 & 0.12 & 1.96 \\
\hline Ireland & 13.0 & 0.394 & 2.53 & 0.85 & 0.55 & 0.37 & 0.50 & 2.52 & 0.80 & 0.25 & 0.35 & 1.03 \\
\hline Netherlands & 6.0 & 0.485 & 2.47 & 0.39 & 0.21 & 0.16 & 1.62 & 2.35 & 0.45 & 0.20 & 0.20 & 1.58 \\
\hline New Zealand & 8.2 & 0.142 & 1.07 & 0.43 & 0.45 & 0.40 & 0.56 & 1.08 & 0.43 & 0.37 & 0.43 & 0.65 \\
\hline Norway & 5.0 & 0.270 & 3.57 & 0.53 & 0.20 & 0.24 & 0.79 & 3.13 & 0.49 & 0.10 & 0.28 & 1.07 \\
\hline Portugal & 5.9 & 0.272 & 6.30 & 0.47 & 0.19 & 0.11 & 0.68 & 6.10 & 0.48 & 0.25 & 0.13 & 0.64 \\
\hline Spain & 20.5 & 0.364 & 3.26 & 0.82 & 0.21 & 0.30 & 1.19 & 2.87 & 0.72 & 0.12 & 0.30 & 2.08 \\
\hline Sweden & 6.8 & 0.248 & 4.75 & 0.67 & 0.22 & 0.23 & 0.65 & 1.83 & 0.52 & 0.25 & 0.29 & 1.07 \\
\hline Switzerland & 3.8 & 0.262 & 0.83 & 0.41 & 0.17 & 0.53 & 1.62 & 0.76 & 0.50 & 0.16 & 0.46 & 1.52 \\
\hline
\end{tabular}


Table 9

Sacrifice ratios estimated from actual developments

Inflation measured as percentage changes in consumption deflators

\begin{tabular}{|c|c|c|c|c|c|c|c|c|c|c|}
\hline \multirow[t]{2}{*}{ Countries } & \multicolumn{5}{|c|}{$1980 \mathrm{~s}$} & \multicolumn{5}{|c|}{$1990 \mathrm{~s}$} \\
\hline & Period & $\Delta \pi$ & $\pi_{\mathrm{o}}$ & $\operatorname{SR}(\Sigma \Delta u)$ & $\mathrm{SR}(\Sigma \Delta g a p)$ & Period & $\Delta \pi$ & $\pi_{\mathrm{o}}$ & $\operatorname{SR}(\Sigma \Delta u)$ & $\mathrm{SR}(\Sigma \Delta g a p)$ \\
\hline United States & $1980-86$ & 8.0 & 10.9 & 0.70 & 1.00 & $1990-98$ & 4.3 & 5.1 & 0.70 & 2.60 \\
\hline Japan & $1980-87$ & 7.0 & 7.5 & 0.55 & 2.35 & $1990-95$ & 3.1 & 2.6 & 0.75 & 3.70 \\
\hline Germany & 1981-86 & 6.8 & 6.2 & 2.15 & 1.50 & $1992-98$ & 3.7 & 4.7 & 4.00 & 6.40 \\
\hline France & 1980-86 & 10.6 & 13.3 & 1.55 & 1.15 & 1991-98 & 2.7 & 3.2 & 6.05 & 5.85 \\
\hline Italy & $1980-87$ & 15.3 & 20.6 & 1.25 & 2.25 & $1991-98$ & 4.6 & 6.9 & 4.05 & 5.15 \\
\hline United Kingdom & $1980-86$ & 12.1 & 16.1 & 2.40 & 0.60 & $1991-98$ & 5.9 & 7.9 & 0.40 & 0.15 \\
\hline Canada $^{1}$ & $1981-85$ & 8.5 & 11.0 & 2.60 & 1.75 & 1989-98 & 4.7 & 4.6 & 4.45 & 6.15 \\
\hline Australia $^{1}$ & $1982-85$ & 5.7 & 11.3 & 0.95 & 0.05 & 1988-94 & 7.6 & 8.7 & 1.50 & 1.40 \\
\hline Belgium & $1980-86$ & 7.6 & 8.6 & 3.30 & 3.55 & $1989-95$ & 2.2 & 4.0 & 4.80 & 5.30 \\
\hline Denmark & $1981-86$ & 9.2 & 12.0 & 0.15 & $<0$ & 1989-93 & 3.9 & 5.0 & 1.60 & 1.45 \\
\hline Finland & 1981-86 & 8.7 & 11.9 & 0.25 & 0.10 & 1990-95 & 5.7 & 6.0 & 8.70 & 10.35 \\
\hline Ireland & $1981-87$ & 17.2 & 19.6 & 2.05 & 0.95 & 1989-93 & 2.2 & 4.1 & $<0$ & 3.10 \\
\hline Netherlands & 1980-84 & 4.9 & 6.8 & 4.05 & 2.20 & $1991-95$ & 1.8 & 3.2 & 2.65 & 3.80 \\
\hline New Zealand & $1980-84$ & 10.7 & 17.9 & 0.60 & $<0$ & 1989-92 & 5.3 & 6.8 & 1.35 & 2.10 \\
\hline Norway & 1981-85 & 7.0 & 12.9 & 0.55 & 0.95 & $1987-94$ & 6.5 & 7.7 & 3.30 & 5.35 \\
\hline Portugal & $1984-87$ & 18.6 & 28.5 & 0.00 & 0.10 & 1989-97 & 11.0 & 13.1 & 0.55 & 1.55 \\
\hline Spain & $1977-85$ & 16.6 & 23.7 & 4.35 & 1.35 & 1989-98 & 4.6 & 6.6 & 6.60 & 7.55 \\
\hline Sweden & $1980-86$ & 8.6 & 13.8 & 0.65 & $<0$ & $1991-96$ & 9.1 & 10.3 & 2.45 & 2.00 \\
\hline Switzerland & $1982-86$ & 4.4 & 5.8 & 0.05 & 1.30 & $1991-98$ & 6.0 & 6.0 & 3.70 & 2.30 \\
\hline Average $^{2}$ & $5^{3}$ & 9.8 & 13.6 & 1.50 & 1.10 & $6^{3}$ & 4.0 & 6.1 & 3.15 & 4.00 \\
\hline Standard dev. & - & 4.2 & 6.1 & 1.3 & 1.0 & - & 2.4 & 2.6 & 2.4 & 2.6 \\
\hline \multicolumn{11}{|c|}{$\begin{array}{l}\text { Notation: } \Delta \pi \text { : change in the rate of inflation over period; } \pi_{\mathrm{o}} \text { : rate of inflation at beginning of period; } \operatorname{SR}(\Sigma \Delta u) \text { : sacrifice ratio calculated as } \\
\text { cumulative change in the rate of unemployment divided by change in the rate of inflation (sign reversed); } \operatorname{SR}(\Sigma \Delta \text { gap }) \text { : sacrifice ratio. } \\
\text { calculated as cumulative change in the output gap divided by change in the rate of inflation (sign reversed). } \\
{ }^{1} \text { GDP deflator. }{ }^{2} \text { Unweighted. }{ }^{3} \text { Average length of period, in years. }\end{array}$} \\
\hline
\end{tabular}


Table 10

Rate of inflation and slope of the aggregate supply curve

Cross-country estimates

\begin{tabular}{|l|c|c|c|c|c|c|c|}
\hline Period & Intercept & $\pi$ & $\sigma_{\Delta y}$ & $\mathrm{R}^{2}$ & Mean $\pi$ & Mean $\sigma_{\Delta y}$ & $\mathrm{R}_{\pi, \sigma}$ \\
\hline $1965-98$ & $0.19(2.5)$ & $0.04(4.6)$ & $0.001(0.9)$ & 0.42 & 6.0 & 4.0 & 0.43 \\
$1965-85$ & $0.19(1.5)$ & $0.03(2.1)$ & $0.011(0.3)$ & 0.34 & 9.5 & 3.95 & 0.58 \\
$1985-98$ & $0.19(1.8)$ & $0.03(1.0)$ & $0.004(0.1)$ & 0.15 & 3.6 & 4.05 & 0.79 \\
$1965 / 85-1985 / 98$ & $0.24(2.0)$ & $0.09(3.8)$ & $0.035(1.3)$ & 0.48 & -4.7 & 0.10 & -0.20 \\
\hline
\end{tabular}

Note: Coefficients obtained from estimating the following equation across the 19 countries and two periods:

$\beta_{i t}=\alpha+\eta \pi_{i t}+\kappa \sigma(\Delta y)_{i t}+\varepsilon_{i t} \quad$ with $i=1, \ldots, 19$ and $t=1,2$.

$\beta_{i t}$ refers to the coefficient on the change in nominal GDP from Table 2 for country $i$ and period $t ; \pi_{\text {it }}$ is the average inflation rate in country $i$ in period $t$ and $\sigma(\Delta \mathrm{y})$ is the standard deviation of nominal GDP growth. The first row shows the estimates from a sample that includes the $\beta$ coefficients for both periods (38 observations). The second and third rows show regressions using only cross-country variation for each period separately (19 observations). The last row shows a regression of the change in $\beta_{i}$ between the two periods on changes in the other variables (the summary statistics shown in the right-hand columns of this row refer to changes as well). Numbers in parentheses are t-statistics.

Table 11

Rate of inflation and slope of the aggregate supply curve

Time series estimates

\begin{tabular}{|l|c|c|c|c|c||c|c|c|c|c|c|}
\hline Countries & $\beta$ & $\beta^{\prime}$ & $\lambda$ & $\lambda^{\prime}$ & \multicolumn{1}{|c|}{$\gamma$} & \multicolumn{2}{|c|}{$1970 \mathrm{~s}$} & \multicolumn{2}{c|}{$1980 \mathrm{~s}$} & \multicolumn{2}{c|}{$1990 \mathrm{~s}$} \\
\hline United States & 0.30 & -0.46 & 0.65 & -1.42 & 0.52 & 0.23 & 0.44 & 0.21 & 0.37 & 0.12 & 0.10 \\
Japan & 0.75 & -0.20 & 0.64 & -0.48 & - & 0.73 & 0.58 & 0.66 & 0.42 & 0.52 & 0.07 \\
Germany & 0.61 & -0.99 & 0.67 & -1.35 & - & 0.43 & 0.42 & 0.28 & 0.22 & 0.24 & 0.17 \\
France & 0.55 & -1.25 & - & - & 0.30 & 0.42 & - & 0.38 & - & -0.12 & - \\
Italy & 0.66 & -0.74 & 0.33 & - & 0.24 & 0.61 & 0.33 & 0.60 & 0.33 & 0.51 & 0.33 \\
United Kingdom & 0.89 & -1.87 & 0.39 & - & - & 0.75 & 0.39 & 0.64 & 0.39 & 0.49 & 0.39 \\
Canada & 0.68 & -1.08 & 0.51 & -0.95 & - & 0.55 & 0.30 & 0.50 & 0.35 & 0.11 & -0.03 \\
Australia & 0.57 & -0.47 & - & - & 0.30 & 0.53 & - & 0.51 & - & 0.35 & - \\
Belgium & 0.70 & -1.05 & - & - & - & 0.56 & - & 0.48 & - & 0.27 & - \\
Denmark & 0.68 & -1.10 & 0.67 & $-1.41^{*}$ & - & 0.57 & 0.53 & 0.51 & 0.45 & 0.11 & -0.06 \\
Finland & 0.54 & -0.46 & 0.15 & - & 0.24 & 0.50 & 0.15 & 0.48 & 0.15 & 0.34 & 0.15 \\
Ireland & 0.88 & -0.27 & 0.39 & - & - & 0.86 & 0.39 & 0.85 & 0.39 & 0.73 & 0.39 \\
Netherlands & 0.35 & -0.11 & 0.23 & - & 0.51 & 0.34 & 0.23 & 0.30 & 0.23 & 0.29 & 0.23 \\
Norway & 0.77 & - & $0.16 *$ & -0.36 & - & 0.77 & 0.12 & 0.77 & 0.11 & 0.77 & -0.03 \\
Spain & 0.50 & -1.05 & - & - & 0.47 & 0.43 & - & 0.40 & - & 0.28 & - \\
Sweden & 0.87 & -1.88 & 0.66 & -2.40 & - & 0.66 & 0.39 & 0.64 & 0.36 & 0.30 & -0.07 \\
\hline
\end{tabular}


Table 12a

Sacrifice ratios, comparative estimates

First period

\begin{tabular}{|c|c|c|c|c|c|c|c|c|c|c|c|c|c|c|}
\hline Countries & $\mathrm{SR}_{1}$ & $\mathrm{SR}_{2,1}$ & $\mathrm{SR}_{2,2}$ & $\mathrm{SR}_{3,1}$ & $\mathrm{SR}_{3,2}$ & $\mathrm{SR}_{4}$ & $\mathrm{SR}_{w}$ & $\mathrm{SR}_{p c}$ & $\mathrm{SR}_{r f}$ & $\mathrm{SR}_{u}$ & $\mathrm{SR}_{q}$ & Mean & St. d. & Rank \\
\hline United States & 4.25 & 3.30 & 1.60 & 2.70 & 2.05 & 4.05 & 1.25 & 2.60 & 1.25 & 0.70 & 1.00 & 2.25 & 1.25 & 18 \\
\hline Japan & 0.45 & 0.40 & 0.35 & 0.40 & 0.40 & 0.60 & 0.15 & 0.60 & 0.25 & 0.55 & 2.35 & 0.60 & 0.60 & 1 \\
\hline Germany & 1.65 & 1.05 & 1.10 & 1.15 & 1.10 & 3.45 & 3.15 & 2.95 & 1.25 & 2.15 & 1.50 & 1.85 & 0.85 & 15 \\
\hline France & 1.25 & 1.35 & 1.25 & 1.35 & 1.25 & 1.90 & 0.85 & 3.30 & 1.50 & 1.55 & 1.15 & 1.50 & 0.65 & 11 \\
\hline Italy & 0.55 & 0.65 & 1.15 & 0.60 & 0.65 & 0.80 & 0.50 & 2.65 & 0.40 & 1.25 & 2.25 & 1.05 & 0.75 & 4 \\
\hline United Kingdom & 0.75 & 0.65 & 0.55 & 0.65 & 0.60 & 2.00 & 5.10 & 3.25 & 3.05 & 2.40 & 0.60 & 1.80 & 1.50 & 14 \\
\hline Canada & 1.25 & 0.90 & 1.00 & 1.00 & 1.20 & 1.65 & 0.45 & 4.15 & 1.35 & 2.60 & 1.75 & 1.65 & 1.05 & 13 \\
\hline Australia & 0.70 & 0.70 & 0.85 & 0.70 & 0.75 & 1.25 & 0.90 & 5.55 & 1.75 & 0.95 & 0.05 & 1.30 & 1.45 & 9 \\
\hline Belgium & 0.80 & 0.40 & 0.35 & 0.60 & 0.60 & 1.45 & 1.10 & 4.05 & 1.15 & 3.30 & 3.55 & 1.60 & 1.35 & 12 \\
\hline Denmark & 1.20 & 1.05 & 0.90 & 1.10 & 1.00 & 0.85 & 2.60 & 3.55 & 1.80 & 0.15 & $<0$ & 1.30 & 1.05 & 9 \\
\hline Finland & 0.70 & 0.25 & 0.30 & 0.45 & 0.30 & 0.55 & 0.15 & 7.35 & 2.10 & 0.25 & 0.10 & 1.15 & 2.15 & 7 \\
\hline Ireland & 0.45 & 0.25 & 0.25 & 0.25 & 0.40 & 0.35 & 0.75 & 1.15 & 0.50 & 2.05 & 0.95 & 0.65 & 0.55 & 2 \\
\hline Netherlands & 1.55 & 1.25 & 2.05 & 1.70 & 2.10 & 1.40 & 1.50 & 4.00 & 1.60 & 4.05 & 2.20 & 2.15 & 1.00 & 17 \\
\hline New Zealand & 0.65 & 0.80 & 1.35 & 0.75 & 0.85 & 1.20 & 4.35 & 1.35 & 0.55 & 0.60 & $<0$ & 1.15 & 1.15 & 7 \\
\hline Norway & 0.30 & 0.20 & 3.40 & 0.25 & 0.90 & 0.35 & 0.65 & 3.80 & 0.80 & 0.55 & 0.95 & 1.10 & 1.25 & 5 \\
\hline Portugal & 0.70 & 0.80 & 0.75 & 0.90 & 0.80 & 0.60 & 0.50 & 4.70 & 0.70 & 0.00 & 0.10 & 0.95 & 1.30 & 3 \\
\hline Spain & 0.65 & 0.95 & 5.35 & 1.00 & 1.45 & 1.10 & 1.15 & 3.35 & 1.20 & 4.35 & 1.35 & 2.00 & 1.60 & 16 \\
\hline Sweden & 1.55 & 1.10 & 1.05 & 0.75 & 1.10 & 1.30 & 0.45 & 3.50 & 0.65 & 0.65 & $<0$ & 1.10 & 0.90 & 5 \\
\hline Switzerland & 6.70 & 3.80 & 2.80 & 3.80 & 3.65 & 2.10 & 2.65 & 2.75 & 1.60 & 0.05 & 1.30 & 2.65 & 1.75 & 19 \\
\hline Mean & 1.35 & 1.05 & 1.40 & 1.05 & 1.10 & 1.40 & 1.45 & 3.40 & 1.25 & 1.50 & 1.10 & 1.45 & 1.25 & - \\
\hline Standard dev. & 1.65 & 1.00 & 1.25 & 0.85 & 0.80 & 0.95 & 1.40 & 1.55 & 0.70 & 1.35 & 1.10 & 0.95 & - & - \\
\hline
\end{tabular}

Notation: All the ratios shown above have been taken from the previous tables, using the following notation: $\mathrm{SR}_{1}\left(\mathrm{Table}_{2}\right) ; \mathrm{SR}_{2,1}$ and $\mathrm{SR}_{2,2}(\mathrm{Table} 3$, first and second column); $\mathrm{SR}_{3,1}$ and $\mathrm{SR}_{3,2}$ (Table 4, first and second line for each country); $\mathrm{SR}_{4}$ (Annex Table 2); $\mathrm{SR}_{w}\left(\right.$ Table 5); $\mathrm{SR}_{p c}\left(\operatorname{Table}^{6}\right) ; \mathrm{SR}_{r f}($ Table 8); and

$\mathrm{SR}_{u}$ and $\mathrm{SR}_{q}$ (Table 9, unemployment and gap-based measures). All the means are unweighted averages. 
Table 12b

Sacrifice ratios, comparative estimates

Second period

\begin{tabular}{|c|c|c|c|c|c|c|c|c|c|c|c|c|c|c|}
\hline Countries & $\mathrm{SR}_{1}$ & $\mathrm{SR}_{2,1}$ & $\mathrm{SR}_{2,2}$ & $\mathrm{SR}_{3,1}$ & $\mathrm{SR}_{3,2}$ & $\mathrm{SR}_{4}$ & $\mathrm{SR}_{w}$ & $\mathrm{SR}_{p c}$ & $\mathrm{SR}_{r f}$ & $\mathrm{SR}_{u}$ & $\mathrm{SR}_{q}$ & Mean & St. $d$. & Rank \\
\hline United States & 6.15 & 6.20 & 6.70 & 6.70 & 6.70 & 7.80 & 1.20 & 3.00 & 1.25 & 0.70 & 2.60 & 4.45 & 2.70 & 18 \\
\hline Japan & 5.25 & 3.40 & 7.70 & 3.30 & 2.90 & 3.35 & 0.20 & 3.30 & 0.25 & 0.75 & 3.70 & 3.10 & 2.20 & 14 \\
\hline Germany & 3.85 & 2.15 & 1.90 & 2.35 & 3.35 & 3.65 & 2.10 & 3.10 & 1.25 & 4.00 & 6.40 & 3.10 & 1.40 & 14 \\
\hline France & 8.10 & 6.10 & 3.95 & 6.10 & 4.65 & 3.10 & 1.00 & 3.55 & 1.60 & 6.05 & 5.85 & 4.55 & 2.15 & 19 \\
\hline Italy & 1.20 & 0.60 & 1.05 & 0.60 & 0.85 & 1.15 & 0.45 & 2.50 & 0.45 & 4.05 & 5.15 & 1.65 & 1.60 & 4 \\
\hline United Kingdom & 2.70 & 1.65 & 1.30 & 1.60 & 2.25 & 2.55 & 1.85 & 5.00 & 2.75 & 0.40 & 0.15 & 2.00 & 1.30 & 7 \\
\hline Belgium & 2.70 & 1.70 & 1.50 & 1.90 & 2.15 & 1.55 & 1.10 & 4.55 & 1.20 & 4.80 & 5.30 & 2.60 & 1.55 & 11 \\
\hline Denmark & 3.55 & 2.40 & 4.10 & 2.35 & 5.25 & 1.55 & 2.80 & 3.70 & 2.00 & 1.60 & 1.45 & 2.80 & 1.20 & 12 \\
\hline Finland & 3.75 & 1.40 & 1.70 & 1.30 & 1.30 & 2.25 & 0.60 & 4.90 & 1.95 & 8.70 & 10.35 & 3.45 & 3.25 & 17 \\
\hline Ireland & 15.65 & 5.00 & 1.75 & 2.05 & 2.05 & 0.80 & 1.05 & 2.60 & 1.05 & $<0$ & 3.10 & 3.20 & 4.35 & 16 \\
\hline Netherlands & 1.55 & 0.90 & 3.20 & 1.25 & 1.55 & 0.90 & 1.40 & 4.00 & 1.60 & 2.65 & 3.80 & 2.05 & 1.15 & 8 \\
\hline Sweden & 1.45 & 0.15 & 0.10 & 0.15 & 0.25 & 1.00 & 1.80 & 2.85 & 1.05 & 2.45 & 2.00 & 1.20 & 1.00 & 1 \\
\hline Switzerland & 2.35 & 1.35 & 2.75 & 1.80 & 4.00 & 2.55 & 2.45 & 3.35 & 1.50 & 3.70 & 2.30 & 2.55 & 0.85 & 10 \\
\hline Mean & 3.45 & 2.05 & 2.45 & 2.05 & 2.45 & 2.15 & 1.45 & 3.75 & 1.35 & 3.05 & 4.00 & 2.50 & 1.75 & - \\
\hline Standard dev. & 3.50 & 1.85 & 1.95 & 1.75 & 1.70 & 1.65 & 1.10 & 1.25 & 0.65 & 2.40 & 2.60 & 1.85 & - & - \\
\hline
\end{tabular}


Table 13

Correlation of sacrifice ratios

\begin{tabular}{|c|c|c|c|c|c|c|c|c|c|c|c|c|}
\hline & $\mathrm{SR}_{1}$ & $\mathrm{SR}_{2,1}$ & $\mathrm{SR}_{2,2}$ & $\mathrm{SR}_{3,1}$ & $\mathrm{SR}_{3,2}$ & $\mathrm{SR}_{4}$ & $\mathrm{SR}_{w}$ & $\mathrm{SR}_{p c}$ & $\mathrm{SR}_{r f}$ & $\mathrm{SR}_{u}$ & $\mathrm{SR}_{q}$ & Mean \\
\hline $\mathrm{SR}_{1}$ & 0.21 & 0.97 & 0.40 & 0.96 & 0.90 & 0.61 & 0.20 & -0.11 & 0.18 & -0.18 & 0.05 & 0.75 \\
\hline $\mathrm{SR}_{2,1}$ & 0.80 & 0.29 & 0.50 & 0.98 & 0.90 & 0.68 & -0.00 & -0.16 & 0.16 & -0.15 & 0.09 & 0.76 \\
\hline $\mathrm{SR}_{2,2}$ & 0.31 & 0.66 & -0.09 & 0.32 & 0.51 & 0.04 & 0.02 & -0.04 & 0.04 & 0.32 & 0.23 & 0.48 \\
\hline $\mathrm{SR}_{3,1}$ & 0.50 & 0.90 & 0.72 & 0.40 & 0.95 & 0.63 & 0.21 & -0.09 & 0.22 & -0.06 & -0.17 & 0.82 \\
\hline $\mathrm{SR}_{3,2}$ & 0.37 & 0.74 & 0.70 & 0.69 & 0.41 & 0.50 & 0.18 & -0.09 & 0.16 & 0.07 & -0.13 & 0.83 \\
\hline $\mathrm{SR}_{4}$ & 0.22 & 0.65 & 0.66 & 0.82 & 0.77 & 0.80 & 0.36 & -0.12 & 0.30 & 0.13 & 0.06 & 0.70 \\
\hline $\mathrm{SR}_{w}$ & -0.22 & -0.18 & -0.14 & -0.18 & 0.07 & -0.11 & 0.75 & -0.27 & 0.47 & 0.06 & -0.28 & 0.37 \\
\hline $\mathrm{SR}_{p c}$ & -0.28 & -0.28 & -0.18 & -0.23 & -0.19 & -0.22 & -0.28 & 0.46 & 0.52 & -0.02 & -0.21 & 0.11 \\
\hline $\mathrm{SR}_{r f}$ & 0.06 & 0.02 & 0.15 & 0.02 & 0.18 & 0.00 & 0.27 & 0.46 & 0.91 & 0.17 & 0.02 & 0.17 \\
\hline $\mathrm{SR}_{u}$ & -0.16 & -0.14 & -0.18 & -0.10 & -0.15 & -0.13 & -0.09 & 0.17 & 0.18 & 0.25 & 0.56 & 0.32 \\
\hline $\mathrm{SR}_{a}$ & 0.05 & 0.00 & -0.03 & -0.05 & -0.18 & -0.06 & -0.26 & 0.11 & 0.24 & 0.89 & 0.32 & 0.21 \\
\hline Mean & 0.63 & 0.85 & 0.64 & 0.81 & 0.71 & 0.65 & -0.17 & 0.02 & 0.51 & 0.22 & 0.31 & 0.20 \\
\hline
\end{tabular}

Table 14

Correlation of changes in sacrifice ratios

\begin{tabular}{|l|c|c|c|c|c|c|c|c|c|c|c|c|}
\hline & $\mathrm{SR}_{1}$ & $\mathrm{SR}_{2,1}$ & $\mathrm{SR}_{2,2}$ & $\mathrm{SR}_{3,1}$ & $\mathrm{SR}_{3,2}$ & $\mathrm{SR}_{4}$ & $\mathrm{SR}_{w}$ & $\mathrm{SR}_{p c}$ & $\mathrm{SR}_{r f}$ & $\mathrm{SR}_{u}$ & $\mathrm{SR}_{q}$ & Mean \\
\hline $\mathrm{SR}_{1}$ & - & 0.88 & 0.37 & 0.59 & 0.39 & 0.20 & 0.01 & 0.16 & 0.24 & -0.17 & 0.07 & 0.74 \\
\hline $\mathrm{SR}_{2,1}$ & & - & 0.72 & 0.82 & 0.67 & 0.47 & -0.08 & 0.17 & 0.07 & -0.05 & 0.05 & 0.88 \\
\hline $\mathrm{SR}_{2,2}$ & & & - & 0.68 & 0.72 & 0.74 & -0.11 & -0.04 & -0.39 & -0.13 & -0.22 & 0.61 \\
\hline $\mathrm{SR}_{3,1}$ & & & & - & 0.81 & 0.68 & -0.07 & 0.07 & -0.12 & -0.09 & -0.05 & 0.79 \\
\hline $\mathrm{SR}_{3,2}$ & & & & & - & 0.69 & -0.20 & 0.05 & -0.22 & -0.08 & -0.13 & 0.65 \\
\hline $\mathrm{SR}_{4}$ & & & & & & - & -0.06 & -0.02 & -0.31 & 0.05 & 0.01 & 0.60 \\
\hline $\mathrm{SR}_{w}$ & & & & & & & - & -0.32 & 0.61 & -0.24 & -0.09 & 0.12 \\
\hline $\mathrm{SR}_{p c}$ & & & & & & & & - & 0.23 & -0.19 & -0.14 & 0.14 \\
\hline $\mathrm{SR}_{r f}$ & & & & & & & & & - & -0.10 & 0.13 & 0.10 \\
\hline $\mathrm{SR}_{u}$ & & & & & & & & & & - & 0.78 & 0.20 \\
\hline $\mathrm{SR}_{q}$ & & & & & & & & & & & - & 0.32 \\
\hline
\end{tabular}


Table 15

Comparison of sacrifice ratios by method of estimation

\begin{tabular}{|c|c|c|c|c|c|c|c|c|c|c|c|c|}
\hline \multirow[t]{3}{*}{ Countries } & \multicolumn{6}{|c|}{ First period } & \multicolumn{6}{|c|}{ Second period } \\
\hline & \multicolumn{2}{|c|}{ Supply curve } & \multicolumn{2}{|c|}{ Structural } & \multicolumn{2}{|c|}{ Actual } & \multicolumn{2}{|c|}{ Supply curve } & \multicolumn{2}{|c|}{ Structural } & \multicolumn{2}{|c|}{ Actual } \\
\hline & SR & Rank & SR & Rank & SR & Rank & SR & Rank & SR & Rank & SR & Rank \\
\hline United States & 3.00 & 18 & 1.70 & 5 & 0.85 & 9 & 6.70 & 19 & 1.80 & 6 & 1.65 & 6 \\
\hline Japan & 0.45 & 3 & 0.35 & 1 & 1.45 & 11 & 4.50 & 16 & 1.25 & 2 & 2.25 & 8 \\
\hline Germany & 1.55 & 15 & 2.40 & 15 & 1.80 & 15 & 2.85 & 14 & 2.30 & 10 & 5.20 & 15 \\
\hline France & 1.40 & 14 & 1.90 & 7 & 1.35 & 10 & 5.35 & 18 & 2.05 & 8 & 5.95 & 17 \\
\hline Italy & 0.75 & 5 & 1.20 & 3 & 1.75 & 14 & 0.90 & 3 & 1.15 & 1 & 4.60 & 12 \\
\hline United Kingdom & 0.85 & 8 & 3.80 & 19 & 1.50 & 12 & 2.00 & 11 & 3.20 & 19 & 0.25 & 1 \\
\hline Canada & 1.15 & 12 & 2.00 & 10 & 2.15 & 16 & 2.15 & 12 & 1.65 & 5 & 5.30 & 16 \\
\hline Australia & 0.80 & 7 & 2.75 & 17 & 0.50 & 6 & 1.60 & 8 & 2.70 & 15 & 1.45 & 3 \\
\hline Belgium & 0.70 & 4 & 2.10 & 11 & 3.40 & 19 & 1.90 & 9 & 2.30 & 10 & 5.05 & 14 \\
\hline Denmark & 1.00 & 11 & 2.65 & 16 & 0.05 & 1 & 3.20 & 15 & 2.85 & 16 & 1.50 & 4 \\
\hline Finland & 0.40 & 2 & 3.20 & 18 & 0.15 & 3 & 1.95 & 10 & 2.50 & 14 & 9.50 & 19 \\
\hline Ireland & 0.30 & 1 & 0.80 & 2 & 1.50 & 12 & 4.55 & 17 & 1.55 & 3 & 1.55 & 5 \\
\hline Netherlands & 1.65 & 16 & 2.35 & 13 & 3.15 & 18 & 1.55 & 7 & 2.35 & 12 & 3.25 & 11 \\
\hline New Zealand & 0.95 & 10 & 2.10 & 11 & 0.30 & 4 & 1.15 & 4 & 2.20 & 9 & 1.75 & 7 \\
\hline Norway & 0.90 & 9 & 1.75 & 6 & 0.75 & 8 & 0.40 & 1 & 3.00 & 17 & 4.35 & 12 \\
\hline Portugal & 0.75 & 5 & 1.95 & 9 & 0.05 & 1 & 1.50 & 6 & 1.55 & 3 & 1.05 & 2 \\
\hline Spain & 1.75 & 17 & 1.90 & 7 & 2.85 & 17 & 1.20 & 5 & 3.10 & 18 & 7.05 & 18 \\
\hline Sweden & 1.15 & 12 & 1.55 & 4 & 0.35 & 5 & 0.50 & 2 & 1.90 & 7 & 2.25 & 8 \\
\hline Switzerland & 3.80 & 19 & 2.35 & 13 & 0.70 & 7 & 2.45 & 13 & 2.45 & 13 & 3.00 & 10 \\
\hline Average & 1.20 & - & 2.05 & - & 1.30 & - & 2.45 & - & 2.20 & - & 3.60 & - \\
\hline
\end{tabular}




\section{Annex tables}

\section{Annex Table 1}

Integration tests

\begin{tabular}{|c|c|c|c|c|c|c|c|}
\hline \multirow[t]{3}{*}{ Countries } & \multicolumn{4}{|c|}{ Rate of inflation } & \multicolumn{3}{|c|}{ Measures of "slack" } \\
\hline & \multicolumn{2}{|c|}{ Consumption deflator } & \multicolumn{2}{|c|}{ GDP deflator } & \multicolumn{2}{|c|}{ Unemployment } & \multirow{2}{*}{$\begin{array}{c}\text { Gap } \\
\text { t-value }\end{array}$} \\
\hline & $\mathrm{t}$-value & $\lambda$ & $\mathrm{t}$-value & $\lambda$ & $\mathrm{t}$-value & $\lambda$ & \\
\hline United States & -1.5 & 0.86 & -1.5 & 0.88 & $-2.7 *$ & 0.73 & $-4.9 * * *$ \\
\hline Japan & -1.4 & 0.80 & -1.5 & 0.79 & -0.7 & 0.92 & -2.5 \\
\hline Germany & $-3.0 * *$ & 0.72 & -1.6 & 0.80 & -1.0 & 0.97 & $-4.1 * * *$ \\
\hline France & -1.4 & 0.89 & -1.2 & 0.93 & -1.5 & 0.96 & $-2.7 *$ \\
\hline Italy & -1.2 & 0.90 & -1.0 & 0.91 & -0.6 & 0.98 & $-3.3 * *$ \\
\hline United Kingdom & -2.1 & 0.80 & -2.1 & 0.76 & -2.1 & 0.92 & $-4.0 * * *$ \\
\hline Canada & -1.7 & 0.86 & -2.0 & 0.81 & -1.9 & 0.88 & $-3.3^{* *}$ \\
\hline Australia & -2.4 & 0.84 & -2.2 & 0.85 & -1.1 & 0.95 & $-3.7 * * *$ \\
\hline Belgium & -2.3 & 0.70 & -2.3 & 0.77 & -1.7 & 0.96 & $-2.6^{*}$ \\
\hline Denmark & -1.4 & 0.88 & -1.4 & 0.89 & -1.6 & 0.94 & $-2.8^{*}$ \\
\hline Finland & -2.2 & 0.76 & -2.2 & 0.76 & $-2.7 *$ & 0.90 & $-4.2 * * *$ \\
\hline Ireland & -1.8 & 0.85 & -1.7 & 0.79 & -1.5 & 0.94 & $-3.1 * *$ \\
\hline Netherlands & -2.0 & 0.78 & -1.7 & 0.84 & $-2.8^{*}$ & 0.85 & $-3.3 * *$ \\
\hline New Zealand & -2.1 & 0.79 & $-3.1 * *$ & 0.60 & -1.2 & 0.95 & $-4.1^{* * *}$ \\
\hline Norway & -2.1 & 0.78 & $-3.1 * *$ & 0.59 & -1.7 & 0.92 & $-2.7^{*}$ \\
\hline Portugal & -1.9 & 0.83 & -1.5 & 0.85 & $-2.7 *$ & 0.86 & $-4.3 * * *$ \\
\hline Spain & -1.5 & 0.87 & -1.5 & 0.89 & -1.7 & 0.97 & $-2.8^{*}$ \\
\hline Sweden & -1.3 & 0.83 & -1.9 & 0.81 & -1.8 & 0.91 & $-3.3 * *$ \\
\hline Switzerland & $-2.8^{*}$ & 0.65 & $-2.6^{*}$ & 0.67 & -1.6 & 0.93 & $-3.3 * *$ \\
\hline
\end{tabular}

Note: The integration tests were done by estimating the following equation on annual data (1965-98):

$\Delta y_{t}=\alpha+(\lambda-1) y_{t-1}+\sum_{1}^{4} \beta_{i} \Delta y_{t-i}$

with $y$ successively set equal to $\Delta p c, \Delta p y, u$ and gap and "t-values" showing the t-statistics for $(\lambda-1)$. Critical values are: $2.65(10 \%$, marked by $*), 2.97(5 \%, * *)$ and $3.70(1 \%, * * *)$. 
Annex Table 2

Sacrifice ratios: alternative estimates

\begin{tabular}{|c|c|c|c|c|c|c|c|c|}
\hline \multirow[t]{2}{*}{ Countries } & \multicolumn{4}{|c|}{$1965-85$} & \multicolumn{4}{|c|}{ 1985-98 } \\
\hline & $\alpha$ & $\eta$ & $\delta$ & SR & $\alpha$ & $\eta$ & $\delta$ & SR \\
\hline United States & 0.19 & 0.49 & 0.05 & 4.05 & 0.11 & 0.23 & 0.13 & 7.80 \\
\hline Japan & 0.59 & 0.37 & $0.01 *$ & 0.60 & 0.23 & 0.19 & 0.03 & 3.35 \\
\hline Germany & 0.22 & 0.34 & 0.05 & 3.45 & 0.22 & 0.35 & 0.06 & 3.65 \\
\hline France & 0.30 & 0.35 & - & 1.90 & 0.24 & 0.33 & $0.01 *$ & 3.10 \\
\hline Italy & 0.52 & 0.25 & $0.03 *$ & 0.80 & 0.45 & 0.18 & $0.04 *$ & 1.15 \\
\hline United Kingdom & 0.31 & 0.48 & $0.02 *$ & 2.00 & 0.27 & 0.43 & $0.03 *$ & 2.55 \\
\hline Canada & 0.36 & 0.51 & - & 1.65 & 0.26 & 0.44 & 0.09 & 2.75 \\
\hline Australia & 0.42 & 0.27 & $0.00 *$ & 1.25 & 0.39 & 0.17 & 0.05 & 1.50 \\
\hline Belgium & 0.39 & 0.29 & $0.08 *$ & 1.45 & 0.38 & 0.36 & - & 1.55 \\
\hline Denmark & 0.51 & 0.40 & 0.07 & 0.85 & 0.39 & 0.21 & - & 1.55 \\
\hline Finland & 0.63 & $0.17 *$ & - & 0.55 & 0.30 & $0.23^{*}$ & $0.10^{*}$ & 2.25 \\
\hline Ireland & 0.70 & 0.23 & - & 0.35 & 0.53 & 0.64 & - & 0.80 \\
\hline Netherlands & 0.40 & 0.11 & 0.11 & 1.40 & 0.52 & 0.22 & - & 0.90 \\
\hline New Zealand & 0.42 & 0.42 & 0.09 & 1.20 & 0.41 & 0.40 & $0.06^{*}$ & 1.35 \\
\hline Norway & 0.72 & 0.24 & $-0.01 *$ & 0.35 & 0.82 & $0.14^{*}$ & $0.07 *$ & 0.20 \\
\hline Portugal & 0.59 & 0.23 & - & 0.60 & 0.32 & 0.24 & 0.14 & 1.85 \\
\hline Spain & 0.45 & 0.28 & $0.03 *$ & 1.10 & 0.40 & 0.32 & 0.10 & 1.40 \\
\hline Sweden & 0.42 & 0.28 & 0.06 & 1.30 & 0.48 & $0.22 *$ & $0.01 *$ & 1.00 \\
\hline Switzerland & 0.31 & 0.45 & 0.08 & 2.10 & 0.27 & 0.45 & $0.00 *$ & 2.55 \\
\hline Average & 0.50 & 0.25 & 0.05 & 1.05 & 0.40 & 0.30 & 0.05 & 1.40 \\
\hline
\end{tabular}

Note: The above estimates are based on the approach in Chand (1997), which takes more explicit account of the nominal income identity and corrects for wage shocks. It starts from the identity:

(i)

$$
\Delta y_{t}=\Delta q_{t}+\pi_{t}
$$

which, by adding and subtracting the lagged rate of inflation as well as the trend rate of output growth ( $\left.\Delta q^{*}\right)$, can be rewritten as:

(ii) $\quad \Delta \pi_{t}+\Delta q_{t}-\Delta q^{*}=\Delta y-\left(\pi_{t-1}+\Delta q^{*}\right)$

This essentially says that the deviation of nominal income growth from the trend rate valued at the inflation rate of the previous period can be split into an acceleration of price inflation and a deviation of real output growth from the potential rate. While (i) and (ii) hold identically, theory can be introduced by assuming that:

(iiia) $\quad \Delta \pi_{t}=\alpha\left(\Delta y-\left(\Delta q *+\pi_{t-1}\right)\right)+\varepsilon_{t}$ and

(iiib) $\quad \Delta q_{t}-\Delta q^{*}=(1-\alpha)\left(\Delta y-\left(\Delta q^{*}+\pi_{t-1}\right)\right)+\varepsilon_{t}^{\prime}$

Temporary supply shocks (import price increases in excess of domestic inflation or increases in unit labour costs $(\Delta u l c)$ as a result of wage earners attempting to increase their share of total factor income) can be allowed for and enter the two equations with opposite signs:

(iva) $\quad \Delta \pi_{t}=\alpha\left(\Delta y-\left(\Delta q^{*}+\pi_{t-1}\right)\right)+\eta\left(\Delta u l c_{t}-\pi_{t-1}\right)+\delta(\Delta p m-\pi)_{t-1} \varepsilon_{t}$ and

(ivb) $\quad \Delta q_{t}-\Delta q^{*}=(1-\alpha)\left(\Delta y-\left(\Delta q^{*}+\pi_{t-1}\right)\right)-\eta\left(\Delta u l c_{t}-\pi_{t-1}\right)-\delta(\Delta p m-\pi)_{t-1} \varepsilon_{t}^{\prime}$

(iva) and (ivb) were estimated without imposing cross-equation constraints. However, since the constraints were easily satisfied in all cases the table only shows the results for (iva).

Notation: $\pi=$ rate of inflation (GDP deflator); $y=$ nominal GDP; $q=$ real GDP; $q^{*}=$ potential GDP; $u l c=$ unit labour costs (total economy); $p m=$ import prices; $\Delta=$ first-difference operator; and sacrifice ratios measured as $(1-\alpha) / \alpha$. All coefficients significant, except when marked by *. 
Annex Table 4

Okun coefficients and implied potential growth rates*

\begin{tabular}{|l|c|c|}
\hline Countries & $\Sigma \beta$ & $\Delta q^{*}$ \\
\hline United States & 0.449 & 2.25 \\
Japan & 0.084 & 4.84 \\
Germany & 0.315 & 3.71 \\
France & 0.582 & 2.16 \\
Italy & 0.150 & 2.43 \\
United Kingdom & 0.561 & 1.71 \\
Canada & 0.542 & 2.16 \\
Australia & 0.435 & 3.30 \\
Belgium & 0.297 & 2.95 \\
Denmark & 0.394 & 1.65 \\
Finland & 0.524 & 3.00 \\
Ireland & 0.394 & 4.85 \\
Netherlands & 0.485 & 2.15 \\
New Zealand & 0.142 & 2.75 \\
Norway & 0.270 & 2.75 \\
Portugal & 0.272 & 3.25 \\
Spain & 0.364 & 3.20 \\
Sweden & 0.248 & 2.95 \\
Switzerland & 0.262 & 1.35 \\
\hline$*$ Coefficients and potential growth rates are obtained by estimating the following \\
equation on annual data $(1965-98$ in most cases): \\
$\Delta U=\alpha+\beta_{1} \Delta \log Q+\beta_{2} \Delta \log Q_{-1}+\delta D U M_{91}-98$ \\
where $U=$ rate of unemployment, $Q=$ real GDP and $D U M_{91-98}$ a dummy variable with \\
1 for $1991-98$ and otherwise 0. Assuming that unemployment is stable when $Q$ grows at \\
the potential rate, the potential rate for $1991-98$ can be calculated as: \\
$\Delta q^{*}=(\delta+\alpha) / \sum \beta$ & & \\
\hline
\end{tabular}

Annex Table 5

Comparison of sacrifice ratios based on actual developments 1980s, gap-based ratios

\begin{tabular}{|l|c|c|c|}
\hline Countries & Ball (1994) & Jordan (1997) & Table 7 \\
\hline United States & 1.95 & 3.45 & 1.00 \\
Japan & $<0$ & 7.65 & 2.35 \\
Germany & 2.05 & 6.80 & 1.50 \\
France & 0.25 & 2.40 & 1.15 \\
Italy & 1.65 & 3.65 & 2.25 \\
United Kingdom & 0.50 & $<0$ & 0.60 \\
Canada & 2.25 & 2.90 & 1.75 \\
Australia & 0.40 & 0.30 & 0.05 \\
Belgium & 1.70 & 3.85 & 3.55 \\
Denmark & 1.75 & 1.30 & $<0$ \\
Finland & 0.65 & 1.10 & 0.10 \\
Ireland & 0.45 & 2.00 & 0.95 \\
Netherlands & 0.40 & 7.55 & 2.20 \\
New Zealand & 0.15 & $<0$ & $<0$ \\
Spain & 3.50 & 2.95 & 1.35 \\
Sweden & 0.15 & 4.25 & $<0$ \\
Switzerland & $<0$ & \multicolumn{3}{|l}{} \\
\hline Note: Bilateral correlations: Ball-Jordan: 0.35; Ball-Table 7: 0.25; and Jordan-Table 7: \\
0.65.
\end{tabular}




\section{References}

Alberro, J (1981): “The Lucas hypothesis on the Phillips curve". Journal of Monetary Economics, pp. 239-50.

Alogoskoufis, G S and R Smith (1991): "The Phillips curve, the persistence of inflation and the Lucas critique: evidence from exchange rate regimes". American Economic Review, pp. 1254-75.

Akerlof, G A, W T Dickens and G L Perry (1996): "The macroeconomics of low inflation". Brookings Papers on Economic Activity, pp. 1-60.

Andersen, P S (1992): "OECD country experiences with disinflation" in A Blundell-Wignall (ed.) Inflation, Disinflation and Monetary Policy, Reserve Bank of Australia, pp. 104-79.

Andersen, T (1997): "Nominal wage and price adjustment to foreign price changes". Journal of Macroeconomics, pp. 419-42.

Anderton, R (1997): "Did the underlying behaviour of inflation change in the 1980s? A study of 17 countries". Weltwirtschaftliches Archiv, pp. 22-38.

Asai, M (1999): "Time series evidence on a new-Keynesian theory of the output-inflation trade-off". Applied Economics Letters, pp. 539-41.

Ball, L (1996): “Disinflation and the NAIRU”. NBER Working Paper, No. 5520.

Ball, L. (1994): "What determines the sacrifice ratio?" in N G Mankiw (ed.) Monetary Policy, University of Chicago Press, pp. 155-82.

Ball, L (1992): “Disinflation with imperfect credibility”. NBER Working Paper, No. 3983.

Ball, L, N G Mankiw and D Romer (1988): "The new-Keynesian economics and the output-inflation trade-off". Brookings Papers on Economic Activity, pp. 1-82.

Bernanke, B, T Laubach, F Mishkin and A Posen (1999): "Inflation Targeting". Princeton University Press.

Blanchard, O J and L Katz (1997): "What do we know and do not know about the natural rate of Unemployment". Journal of Economic Perspectives, pp. 52-72.

Bleaney, M (1996): "Central bank independence, wage-bargaining structure and macroeconomic performance in OECD countries". Oxford Economic Papers, pp. 20-38.

Braun, S (1987): "Productivity and the NAIRU". Board of Governors of the Federal Reserve System, Economic Activity Section Working Paper.

Burdekin, R C and P L Siklos (1999): "Exchange rate regimes and shifts in inflation persistence: does nothing else matter?" Journal of Money, Credit and Banking, pp. 235-47.

Cecchetti, S G (1994): “Comment" in N G Mankiw (ed.) Monetary Policy, University of Chicago Press, pp. 188-93.

Cecchetti, S G and R W Rich (1999): "Structural estimates of the US sacrifice ratio". Federal Reserve Bank of New York, Staff Report, No. 71. 
Chadha, B, P R Masson and G Meredith (1992): "Models of inflation and the costs of disinflation". IMF Staff Papers, pp. 395-431.

Chand, K Sheetal (1997): "Nominal income and the inflation-growth divide". IMF Working Paper.

Chapple, B and A Yates (1996): "What determines the short-run output-inflation trade-off?" Bank of England, Working Paper, No. 53.

Christensen, M and M Paldam (1989): "Some further international evidence on output-inflation trade-offs: the Lucas variability hypothesis re-examined" pp. 222-37.

Debelle, G (1996): "The end of three small inflations: Australia, New Zealand and Canada". Canadian Public Policy, pp. 56-78.

Debelle, G and S Fischer (1994): "How independent should central banks be?" in J C Fuhrer (ed.) Goals, Guidelines and Constraints Facing Monetary Policymakers, Federal Reserve Bank of Boston, pp. 195-222.

Filardo, A (1998): "New evidence on the output cost of fighting inflation". Federal Reserve Bank of Kansas City, Economic Review, 3rd quarter.

Froyen, R T and R N Waud (1980): "Further international evidence on output-inflation trade-offs". American Economic Review, pp. 409-21.

Fuhrer, J C (1995): "The persistence of inflation and the cost of disinflation". Federal Reserve Bank of Boston, New England Economic Review, January/February.

Fuhrer, J C (1997): "Central bank independence and inflation targeting: monetary policy paradigms for the next millennium", Federal Reserve Bank of Boston, New England Economic Review, January/February.

Gali, J and M Gertler (1998): "Inflation dynamics: a structural econometric analysis". Paper presented on conference on The Return of the Phillips curve, Studienzentrum Gerzensee, 7-10 October.

Gordon, R J (1981): "Output fluctuations and gradual price adjustments". Journal of Economic Literature, pp. 493-530.

Gordon, R J (1982a): "Why stopping inflation may be costly: evidence from fourteen historical episodes" in R Hall (ed.) Inflation: Causes and Effects, Chicago University Press, pp. 9-40.

Gordon, R J (1982b): "Price inertia and policy ineffectiveness in the United States, 1890-1980". Journal of Political Economy, pp. 1087-117.

Gordon, R J (1999a): "The aftermath of the 1992 ERM breakup: was there a macroeconomic free lunch?” NBER Working Paper, No. 6964.

Gordon, R J (1999b): "Foundations of the Goldilocks economy: supply shocks, and the time-varying NAIRU”. Brookings Papers on Economic Activity, pp. 297-333.

Gordon, R J and S R King (1982): "The output cost of disinflation in traditional and vector autoregressive models". Brookings Papers on Economic Activity, pp. 205-42.

Grubb, D, R Jackman and R Layard (1983): "Wage rigidity and unemployment in OECD countries". European Economic Review, pp. 11-39. 
Hess, G D and K Shin (1995): "Some international evidence on output-inflation trade-offs". Federal Reserve Bank of Kansas City, Research Working Paper, No. 95-11.

Hutchison, M M and C E Walsh (1998): "The output-inflation trade-off and central bank reform: evidence from New Zealand”. Economic Journal, pp. 703-25.

Jordan, T J (1997): "Disinflation costs, accelerating inflation gains and central bank independence". Weltwirtschaftliches Archiv, pp. 1-21.

Kiley, M T (1996): "Endogenous Price Stickiness and Business Cycle Persistence". Board of Governors of the Federal Reserve System, FEDS Working Paper, No. 96-23.

King, R G and M W Watson (1994): "The post-war US Phillips curve: a revisionist econometric history". Carnegie-Rochester Conference Series on Public Policy, pp. 157-219.

Lucas, R E (1973): "Some international evidence on output-inflation trade-offs". American Economic Review, pp. 326-34.

Lucas, R E (1976): "Errata. Some international evidence on the output-inflation trade-off". American Economic Review, p. 985.

Mankiw, N Gregory (1991). Macroeconmics. New York. Worth Publishers.

Okun, A (1962): "Potential GNP: its measurement and significance". Proceedings of the American Statistical Association, pp. 98-104.

Okun, A (1978): "Efficient disinflationary policies". American Economic Review, pp. 348-52.

Posen, A (1998): “Central bank independence and disinflationary credibility: a missing link?" Oxford Economic Papers, pp. 335-59.

Walsh, C E (1995): "Central bank independence and the costs of disinflation in the European Community" in B Eichengreen, J Frieden and J von Hagen (eds.) Monetary and Fiscal Policy in an Integrated Europe, pp. 12-37. 



\section{Recent BIS Working Papers}

No.

Title

66

April 1999

67

May 1999

68

May 1999

69

June 1999

70

June 1999

71

June 1999

72

August 1999

73

August 1999

74

August 1999

75

August 1999

76

October 1999

77

October 1999

78

October 1999

79

November 1999

80

November 1999

81

November 1999
Evolving international financial markets: some implications for central banks

The cyclical sensitivity of seasonality in US employment

The evolution of determinants of emerging market credit spreads in the 1990s

Credit channels and consumption in Europe: empirical evidence

Interbank exposures: quantifying the risk of contagion

The term structure of announcement effects

Reserve currency allocation: an alternative methodology

The Taylor rule and interest rates in the EMU area: a note

The dollar-mark axis

A note on the Gordon growth model with nonstationary dividend growth

The price of risk at year-end: evidence from interbank lending

Perceived central bank intervention and market expectations: an empirical study of the yen/dollar exchange rate, 1993-96

Banking and commerce: a liquidity approach

Pass-through of exchange rates and import prices to domestic inflation in some industrialised economies

A note on alternative measures of real bond rates

Interbank interest rates and the risk premium
Author

William R White

Spencer Krane and William Wascher

Steven B Kamin and Karsten von Kleist

Gabe de Bondt

Craig H Furfine

Michael J Fleming and Eli M Remolona

Srichander

Ramaswamy

Stefan Gerlach and

Gert Schnabel

Gabriele Galati

Henri Pagès

Craig H Furfine

Gabriele Galati and William Melick

Joseph G Haubrich and João A C Santos

Jonathan McCarthy

Palle S Andersen

Henri Pagès 


ISSN 1020-0959 